\title{
Heterogeneity in southern Central Indian Ridge MORB: Implications for ridge-hot spot interaction
}

\author{
Bramley J. Murton \\ Southampton Oceanography Centre, Waterfront Campus, Empress Dock, Southampton, SO14 3ZH, UK \\ (bjm@soc.soton.ac.uk)
}

Andrew G. Tindle

Department of Earth Sciences, Open University, Milton Keynes, MK7 6AA, UK

\section{J. Andrew Milton}

Southampton Oceanography Centre, Waterfront Campus, Empress Dock, Southampton, SO14 3ZH, UK

\section{Daniel Sauter \\ Institut de Physique du Globe, Université Louis Pasteur, 5 Rue René Descartes, 67084 Strasbourg Cedex, France}

[1] Between the Rodrigues Triple Junction and the Marie Celeste fracture zone, basalts from the Central Indian Ridge (CIR) exhibit an enrichment in incompatible elements that increases in intensity northward. In addition, $\mathrm{H}_{2} \mathrm{O} / \mathrm{TiO}_{2}, \mathrm{Al}_{[8]}$, and $\mathrm{Dy} / \mathrm{Yb}$ ratios increase, while $\mathrm{Na}_{[8]}$ remains unchanged and $\mathrm{Fe}_{[8]}$ decreases. Evolution of the enriched magma appears to be affected by elevated water contents, which lower the mantle solidus, thereby increasing the initial depth of melting, as well as delaying plagioclase crystallization. However, the enrichment affecting the northern samples is not a just function of hydrous mantle melting and crystallization. Instead of trending toward a small melt fraction from the mantle, as predicted by hydrous melting models, the CIR samples lie on a mixing line between N-MORB and a source component that closely resembles present-day Réunion hot spot lavas. Thus it appears that while hydrous melting and crystallization affect the CIR, the enriched and wet mantle originates from the Réunion hot spot, where it migrates eastward toward the CIR, against the direction of motion of the lithosphere.

Components: 12,657 words, 15 figures, 3 tables.

Keywords: Central Indian Ridge; hot spot-ridge interaction; MORB geochemistry.

Index Terms: 1021 Geochemistry: Composition of the oceanic crust; 1037 Geochemistry: Magma genesis and partial melting (3619); 1032 Geochemistry: Mid-oceanic ridge processes (3614, 8416); 1036 Geochemistry: Magma chamber processes (3618); 1038 Geochemistry: Mantle processes (3621).

Received 8 July 2004; Revised 12 January 2005; Accepted 9 February 2005; Published 19 March 2005.

Murton, B. J., A. G. Tindle, J. A. Milton, and D. Sauter (2005), Heterogeneity in southern Central Indian Ridge MORB: Implications for ridge-hot spot interaction, Geochem. Geophys. Geosyst., 6, Q03E20, doi:10.1029/2004GC000798.

Theme: Plume-Ridge Interaction

Guest Editor: David Graham

\section{Introduction}

[2] Although mantle hot spots affect about 20\% of all ocean crust [Weinstein and Olson, 1989], the way they influence neighboring mid-ocean ridges (MOR) is unclear. In places, the presence of "V"-shaped ridges bounding some anomalously shallow MOR is evidence for mantle flowing 
laterally away from hot spots and along the ridge axis (e.g., for the Reykjanes Ridge [Vogt, 1971, 1974; Vogt and Johnson, 1972; White et al., 1995]). Numerical simulations support such inferences by predicting low-viscosity, buoyant, hot spot mantle is channeled along zones of thin lithosphere toward MOR, where it is consumed by lithospheric spreading [Feighner and Richards, 1995; Sleep, 1996; Yale and Morgan, 1998]. Alternatively, where hot spot mantle viscosity increases (e.g., due to dehydration melting [Ito, 2001]), the models predict a radial spread of material away from the loci of plume upwelling.

[3] Additionally, ridge-hot spot interaction is often indicated by a gradient in source compositions with distance along a ridge axis. While such geochemical gradients suggest mingling between enriched hot spot material and depleted mantle, at a length scale of hundreds of kilometers [Mahoney et al., 1989; Schilling et al., 1983], recent work has shown that hydrous mantle melting can also have a substantial effect on the composition and volume of melt production [Detrick et al., 2002; Asimow and Langmuir, 2003; Asimow et al., 2004; Cushman et al., 2004]. This raises the question of to what extent hot spot-ridge interaction is an effect of migration of hot and enriched mantle away from hot spots toward ridges, and how much is a consequence of hydrous melting of a broad and probably static compositional heterogeneity in the mantle beneath a ridge? The former interpretation implies some sort of vertical flux of mantle supplying melt to hot spots, with lateral advection of hot spot mantle toward an adjacent spreading ridge while preserving its enriched composition. In contrast, the latter interpretation does not require any mantle flow specific to a hot spot and instead only needs a compositional heterogeneity causing enhanced mantle melting.

[4] Here, we report variations in basalt composition along the southern Central Indian Ridge (CIR). Until now, this region has only been sparsely studied. Our new data indicate diversity in source composition, systematic changes in melting depth, mantle mixing and hydrous effects on fractional crystallization. We discuss the origin of the incompatible element enrichment of basalts erupted along the CIR closest to the Réunion hot spot; the effects of elevated magmatic water content, and the relationship between the enriched CIR basalts and those of La Réunion.

\section{Geological Setting}

[5] The CIR initiated during separation of the Mascarene Plateau from the Chagos-Lacadives Ridge (Figure 1) about 38 Ma [McKenzie and Sclater, 1971; Schlich, 1982; Patriat and Achache, 1984; Fisk et al., 1989]. These features, in turn, are thought to record the ancient trace of a mantle plume from its earliest manifestation as a precursor to the Deccan Traps, in northwest India, to the present-day as the Réunion hot spot [Morgan, 1981; Cox and Hawksworth, 1984; Fisk et al., 1989; Basu et al., 1993; Mahoney et al., 2002]. Today, the CIR is a slow-intermediate spreading-rate plate boundary, separating at $43 \mathrm{~mm}$ per year full rate toward an azimuth of N63.9E [DeMets et al., 1994; Royer et al., 1997; Muller et al., 1993].

[6] The CIR has morphology typical of slow to intermediate spreading ridges, with a 500 to $1000 \mathrm{~m}$ deep axial valley, 50 to $100 \mathrm{~km}$ long segments terminated by short $(<30 \mathrm{~km}$ long $)$ transform faults and (10 km long) nontransform discontinuities [Parson et al., 1993]. Volcanic accretion within the ridge axis is focused on narrow, axial volcanic ridges (AVRs). These are $1-2 \mathrm{~km}$ wide and up to $15 \mathrm{~km}$ long, rise $100-$ $200 \mathrm{~m}$ above the axial floor, and are aligned orthogonal to the plate separation direction. Young AVRs have a hummocky texture with strong acoustic backscatter that is typical of unsedimented, zero age lava [Blondel and Murton, 1997].

[7] The depth of the CIR generally increases from $2825 \mathrm{~m}$ to $3380 \mathrm{~m}$, over a distance of about $500 \mathrm{~km}$ south of the Marie Celeste fracture [Sandwell and Smith, 1992; General Bathymetric Chart of the Oceans (GEBCO), 2003]. This elevation anomaly in the axial depth suggests a northward increase in the thickness of crust or decrease in density of the mantle. At a latitude of about $21^{\circ} \mathrm{S}$, first and second order offsets in the trend of the ridge axis switch from right-lateral to left-lateral, and remain so until $18^{\circ} \mathrm{S}$ (i.e., at the Marie Celeste fracture zone) where they revert to right-lateral [Parson et al., 1993]. As a result, the ridge axis deviates westward, bringing it closest to the island of $\mathrm{La}$ Réunion at $\sim 18.5^{\circ} \mathrm{S}$. An eastwest oriented ridge (the Rodrigues Ridge (RR)) 


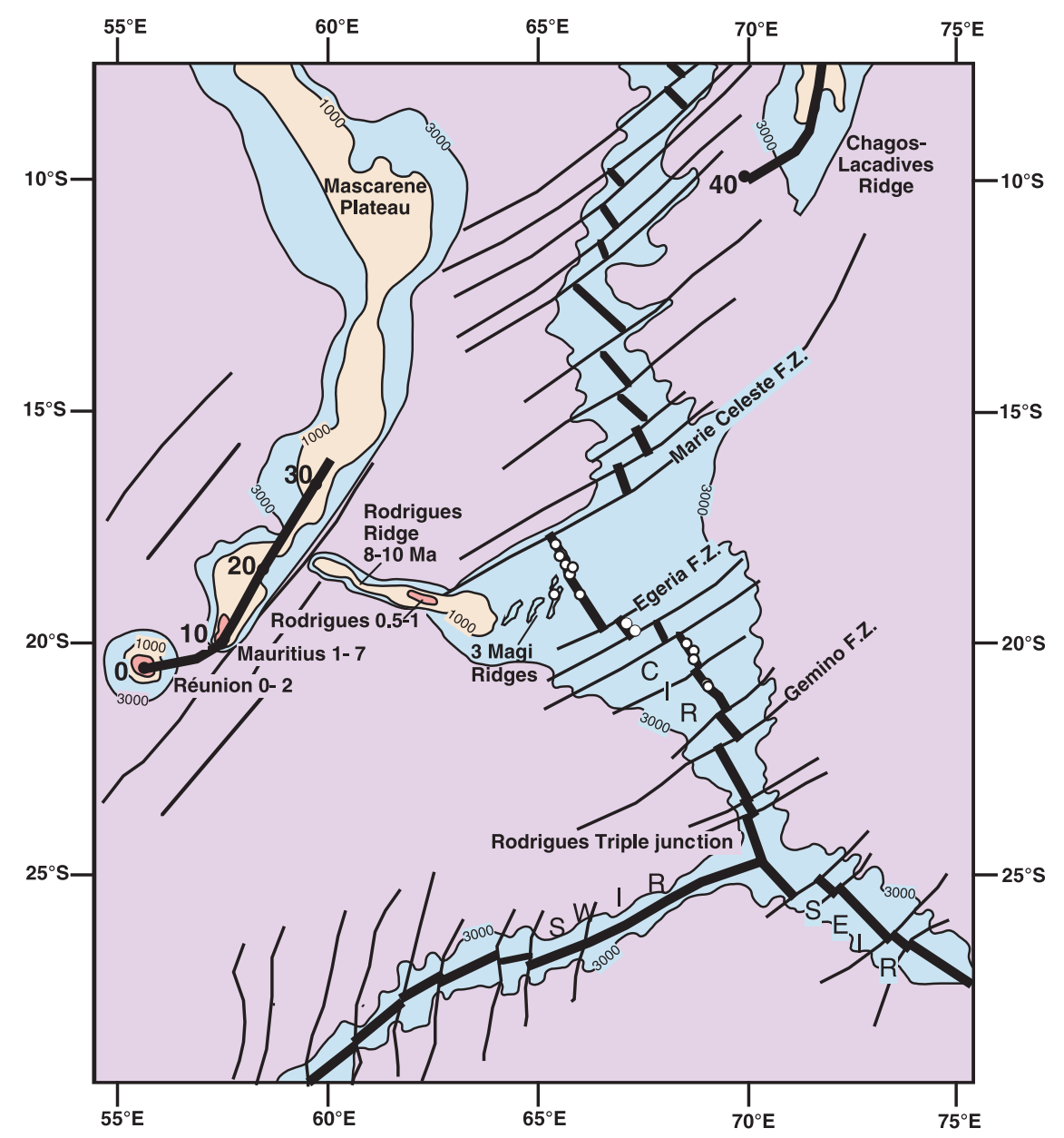

Figure 1. Location map and general bathymetry of the Central Indian Ridge (CIR) and its major fracture zones, showing the Rodriguez Triple Junction, the Southwest Indian Ridge (SWIR), the Southeast Indian Ridge (SEIR), the islands of Réunion, Mauritius, Rodriguez, the Mascarene Plateau, the Chagos-Lacadives Ridge, the Rodriguez Ridge, and the Three Magi Ridges. The $3000 \mathrm{~m}$ and $1000 \mathrm{~m}$ isobaths are also shown, as well as the inferred trace of the Réunion Plume (solid black line) [after Fisk et al., 1989; Duncan, 1990; Muller et al., 1993] and its ages in millions of years (large numbers adjacent to filled black circles). The open circles indicate the positions of samples used in this study. The exact positions are reported in Table 1. The bathymetry, drawn from GEBCO [2003] and Sandwell and Smith [1992], shows a triangular-shaped region of shallow bathymetry decreasing south from the Marie Celeste fracture zone.

that passes through the islands of Mauritius and Rodrigues was interpreted by Morgan [1978] to indicate an extension of Réunion hot spot mantle toward the CIR. It is now known that this lineament almost reaches the CIR at $19^{\circ} \mathrm{S}$, via a series of en echelon ridges (the Three Magi [Dyment et al., 1999]).

[8] Of the five samples that have so far been reported from along the southern CIR, within our study area, those adjacent to the Marie Celeste fracture zone at $\sim 18^{\circ} \mathrm{S}$ are enriched in incompatible trace elements and have low $\varepsilon \mathrm{Nd}$, high ${ }^{207} \mathrm{~Pb} /{ }^{204} \mathrm{~Pb}$, high ${ }^{208} \mathrm{~Pb} /{ }^{204} \mathrm{~Pb}$, high ${ }^{3} \mathrm{He} /{ }^{4} \mathrm{He}$ and high ${ }^{87} \mathrm{Sr} /{ }^{86} \mathrm{Sr}[$ Mahoney et al., 1989]. This isotopic and elemental enrichment resembles a similar enrichment affecting the composition of basalts from the Réunion hot spot (including the neighboring islands of Rodrigues and Mauritius [McDougall and Chamalaun, 1969; Baxter, 1976; Graham et al., 1990]), the Mascarene Plateau and the ChagosLacadives Ridge [Duncan and Pyle, 1988; 
Courtillot et al., 1988; Fisk et al., 1988; White et al., 1990].

[9] Thus the decrease in depth of the CIR, the presence of an east west oriented seafloor lineament, and isotopic similarities with La Réunion, suggest that the ridge is affected by the Réunion hot spot. However, at its closest point (at $18.5^{\circ} \mathrm{S}$ ), the hot spot is located about $1100 \mathrm{~km}$ to the west of the CIR.

\section{Methods}

\subsection{Sampling}

[10] Our study of the CIR was made during cruise CD127 (April-May 2001) of the RRS Charles Darwin. Sample stations were located using multibeam bathymetry coupled with deeptowed side-scan sonar images (from the $30 \mathrm{kHz}$ TOBI system [Murton et al., 1992]) to ensure accurate targeting of young AVRs on the axial floor. Navigation was by GPS. A total of 29 individual stations were sampled between $18.35^{\circ} \mathrm{S}$ and $20.6^{\circ} \mathrm{S}$ (Figure 1). Sample recovery was primarily made using a $500 \mathrm{~kg}$ rock-corer returning, on average, $10 \mathrm{~g}$ of glassy material from each deployment.

\subsection{Preparation and Analyses}

[11] After washing, fresh-looking samples were hand picked under a binocular microscope to ensure they were essentially glassy and free of alteration. Of the 29 samples reported here, all are avesicular, $60 \%$ are aphyric. The remainder have variable amounts of plagioclase and occasionally olivine phenocrysts $(0.1$ to $1.5 \mathrm{~mm}$ in diameter) which, taken together, form less than $5 \%$ by volume. Individual subsamples were analyzed for major elements by electron microprobe (EMP) using a four-spectrometer, wavelength dispersive Cameca SX100 instrument. The electron beam was defocused to $20 \mu \mathrm{m}$, to maximize the excitation volume while minimizing volatile loss, with an acceleration voltage of $20 \mathrm{kV}$, a current of $20 \mathrm{nA}$ and an acquisition time of $120 \mathrm{~s}$ for each element. Calibration was made against internal standards and drift was monitored using a naturally occurring kearsutite amphibole. An international basaltic standard (BIR-1g), of similar composition to the CIR basalts, was analyzed to check for precision. Each unknown was analyzed at ten individual spots, avoiding close proximity to any embedded alteration or crystalline areas. The results are given in Table 1 along with errors (two-sigma standard deviation based on the reproducibility of the data).

[12] Minor and trace elements were analyzed on the same glass samples by laser ablation ICP-MS. This method was chosen on similar grounds to the use of EMP: i.e., to ensure only fresh glass is analyzed, to minimize the effects of crystal content, and to ensure both trace element and major element analyses are from the same material, thus minimizing the effects of small scale heterogeneity. An excimer laser beam was used with a pulse repetition rate of $4 \mathrm{~Hz}$, a preablation time of $10 \mathrm{~s}$, and an acquisition time of $20 \mathrm{~s}$ for each $30 \mu \mathrm{m}$ diameter spot. Data for each sample were averaged from ten different spots. Drift and mass bias was corrected using a synthetic glass standard reference material (SRM NIST-610) that was analyzed between each unknown sample. Blanks were analyzed after each standard. Concentrations of ${ }^{44} \mathrm{Ca}$ were used to determine total $\mathrm{Ca}$ concentrations, that were then compared with total $\mathrm{Ca}$ concentrations measured by EMP, and the difference used to correct for variable laser ablation rates. Accuracy for the rare earth element analyses was assessed by comparison of an internal standard reference material (BRR-1, a basaltic glass analyzed by isotope dilution thermal mass spectrometry). Accuracy for the trace elements was assessed by comparison of SRM NIST610 (where analyzed as an unknown sample) with its accepted values reported by Pearce et al. [1997]. Precision errors are reported as two sigma standard deviations (based on repeatability) and are given in Table 2.

[13] Water contents for a subset of twelve glass samples were analyzed using Fourier transform infrared laser spectroscopy (FTIR) on $200 \mu \mathrm{m}$ thick wafers. Conversion of IR absorption to concentration of dissolved $\mathrm{H}_{2} \mathrm{O}$ was made following the method of Stolper [1982], using a density for the glass of $2.91 \mathrm{cc} \mathrm{g}^{-1}$, interrogating the absorption peak height at $3550 \mathrm{~cm}^{-1}$ (attributed to the $\mathrm{OH}$ fundamental stretch vibration) while assuming a linear background between 3800$2500 \mathrm{~cm}^{-1}$, and using a molar absorption coefficient $(\varepsilon)$ for mid-ocean ridge basalt (MORB) glass of $62 \mathrm{~L} / \mathrm{mol} \mathrm{cm} \mathrm{[Pandya} \mathrm{et} \mathrm{al.,} \mathrm{1992;} \mathrm{Dixon} \mathrm{et}$ $a l .$, 1995]. Peak heights were taken as an average of five spectra for each sample from which the average and two sigma standard deviations are reported in Table 2. Errors for the total water content, of the order of $\pm 5 \%$, are attributed to 


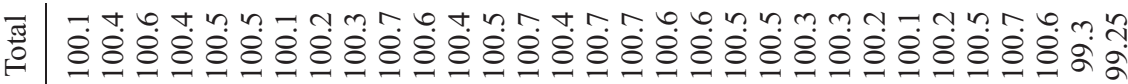

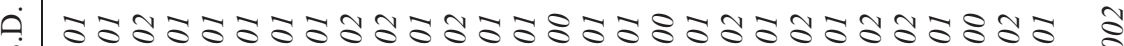

ते 00000000000000000000000000000

๙

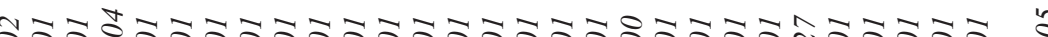

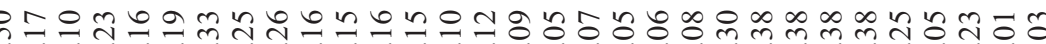

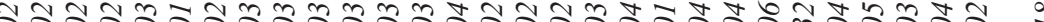

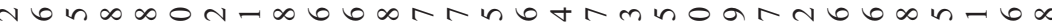

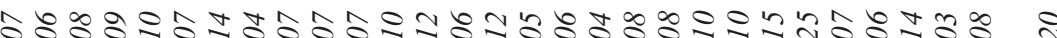

सล 00000000000000000000000000000 तै

-

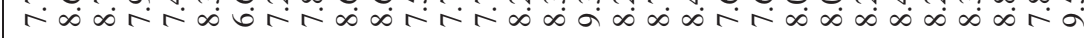

๘

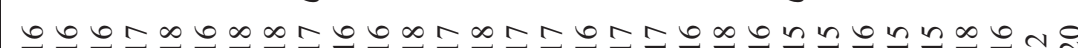

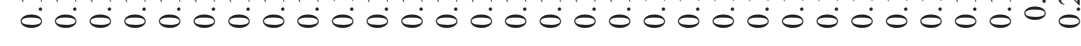

ॠ

กnn

nก

0000000000000000000000000000000

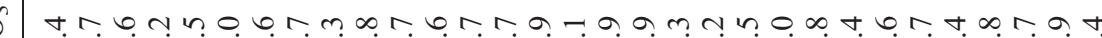

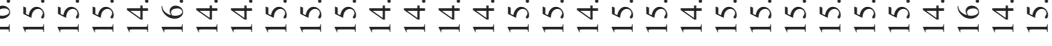

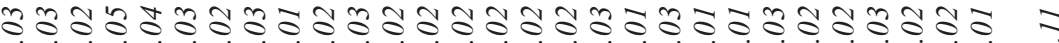

ナ. -

๘ें

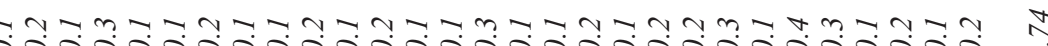

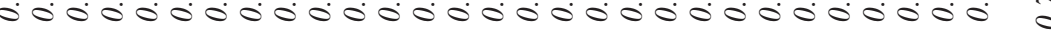

t.

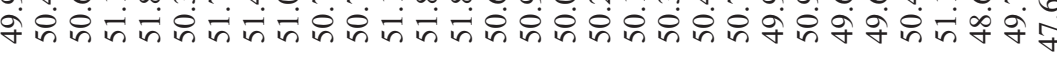

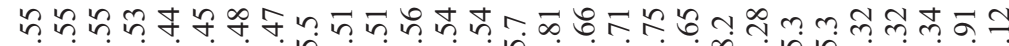
బูं

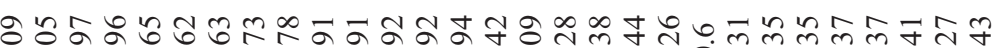

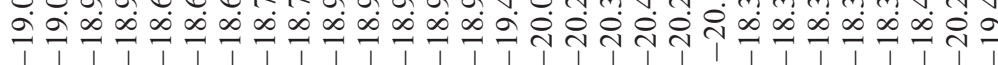

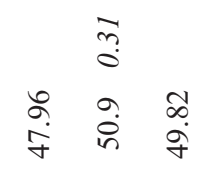

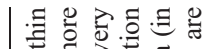

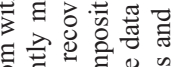

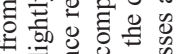
w w

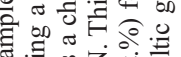

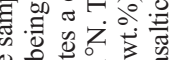
궁월 으원듀 论

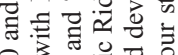

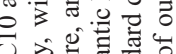
บ 论

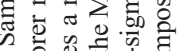
की

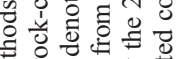

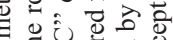

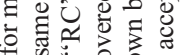

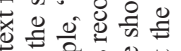

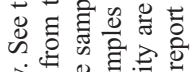

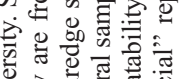
궁혈

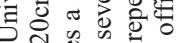

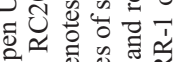

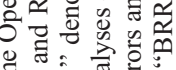

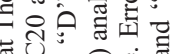
స

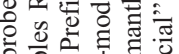

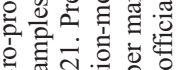

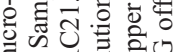

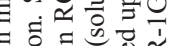

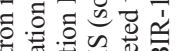
造专 $\sum_{1}^{n} \frac{0}{0}$

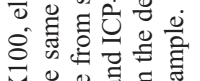

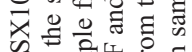

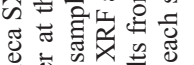

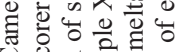

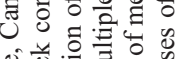

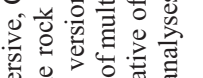

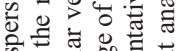
क्⿹勹巳 
uncertainties in wafer thickness $(200 \pm 5 \mu \mathrm{m})$ and $\varepsilon(62 \pm 3 \mathrm{~L} / \mathrm{mol} \mathrm{cm})$.

\section{Results}

\subsection{Major Element Geochemistry}

[14] The samples recovered from the CIR range from N-MORB (normal mid-ocean ridge basalt [Sun et al., 1979; Hofmann, 1988]) to enriched basalt, having $\mathrm{MgO}$ from 6.48 to 9.26 wt.\%, $\mathrm{SiO}_{2}$ from 48.63 to 51.84 wt.\%, and combined $\mathrm{Na}_{2} \mathrm{O}$ and $\mathrm{K}_{2} \mathrm{O}$ contents from 2.3 (in the south) to 3.4 wt.\% (in the north). Mg\# ranges from 51.3 to 63.9, but shows no systematic variation with distance along the ridge. Against $\mathrm{MgO}$, the samples show a broadly negative correlation for $\mathrm{Na}_{2} \mathrm{O}, \mathrm{TiO}_{2}$ and $\mathrm{FeO}$, while $\mathrm{CaO}$ and $\mathrm{Al}_{2} \mathrm{O}_{3}$ show a positive correlation (Figure 2). On most of these diagrams the southernmost samples (from between $20^{\circ} \mathrm{S}$ and $21^{\circ} \mathrm{S}$ ) form a relatively tight and linear group. Compared with samples further north, this group also has lower $\mathrm{K}_{2} \mathrm{O}, \mathrm{P}_{2} \mathrm{O}_{5}, \mathrm{Al}_{2} \mathrm{O}_{3}$ and higher $\mathrm{FeO}$, for a given concentration of $\mathrm{MgO}$, while $\mathrm{NaO}$ and $\mathrm{TiO}_{2}$ do not show any significant differences between groups. Of the oxides plotted, $\mathrm{K}_{2} \mathrm{O}$ and $\mathrm{P}_{2} \mathrm{O}_{5}$ show the poorest correlation with $\mathrm{MgO}$. However, $\mathrm{K}_{2} \mathrm{O}$ does show a tight linear correlation with $\mathrm{P}_{2} \mathrm{O}_{5}$, suggesting a similar process affects both elements (Figure 2). Furthermore, ratios (to $\mathrm{TiO}_{2}$ ) of $\mathrm{K}_{2} \mathrm{O}, \mathrm{H}_{2} \mathrm{O}$ and $\mathrm{P}_{2} \mathrm{O}_{5}$ show a progressive increase with distance northward along the CIR (Figure 3a).

[15] While major element systematics generally give information about the magmatic evolution of basaltic systems (e.g., their fractional crystallization history), both sodium and iron content normalized to a common value of magnesium (usually $8 \% \mathrm{MgO}$ ), to correct for low-pressure crystallization, may yield information about the conditions of source melting [Klein and Langmuir, 1987]. For the CIR, correction of element concentrations to a common $\mathrm{MgO}$ content (e.g., 8 wt.\%) uses a linear liquid line of decent (LLD), defined by the southern group of samples, that is assumed to apply to all the CIR basalts (see caption to Figure $3 \mathrm{~b}$ for a fuller explanation). Along the CIR, apparent $\mathrm{Fe}_{[8]}$ values (often used as a proxy for depth of melting) show a marked and systematic decrease with decreasing latitude. In contrast, apparent $\mathrm{Na}_{[8]}$ values (often used as a proxy for mean melt fraction) show no significant change (Figure $3 b$ ). Although the northward variation of these parameters could be taken to imply a decrease in depth of melting, with no systematic change in mean melt fraction, such interpretations are subject to the crystallization history of the magmas concerned and their source compositions, hence the we use the term "apparent" to describe the element [8] values reported here. For example, if the LLD assumed for the CIR does not apply to the central and northern samples, then the variation in element [8] values is an artifact of the fractionation conditions and not the mantle source its melting.

\subsection{Trace Element Geochemistry}

[16] The trace element geochemistry described here is used to explore variations in source composition and melting. Elements that show strongly incompatible behavior in mafic minerals are particularly useful since their ratios are not significantly affected by low-pressure basaltic crystallization. Hence they are often used to indicate characteristics such as source composition and melting. There is a large variation in the concentration of such incompatible elements along the CIR, with the northern samples being the most enriched (Figure 4a). For $\mathrm{Rb}, \mathrm{Ba}$ and $\mathrm{Nb}$, the increase northward is up to ten-fold. In contrast, $\mathrm{Y}$ and $\mathrm{Yb}$ have lower concentrations in the northern samples than the more southerly ones. The northward increase in incompatible element concentration is demonstrated by the variation of $\mathrm{La} / \mathrm{Sm}$, which increases 2.5-fold from south to north. (Figure 4b). Two samples lie off this trend: 3 Magi (e.g., D5-2) and RC-1. Sample D5-2 was taken from one of the off-axis, en echelon ridges (called the Three Magi) forming the eastward prolongation of the RR (Figure 1). Sample RC-1 was taken from an older AVR close to the western axial valley wall at a $19^{\circ} 05^{\prime} \mathrm{S}$.

[17] Most incompatible trace element ratios correlate with one another, as well as with $\mathrm{K}_{2} \mathrm{O}, \mathrm{P}_{2} \mathrm{O}_{5}$ and $\mathrm{H}_{2} \mathrm{O}$ (Figure 5). These correlations suggest a common process controls the concentrations of the incompatible elements. However, some elements show more complex behavior. For example, the northern samples are mostly displaced toward lower $\mathrm{Y}$ values, at similar concentrations of $\mathrm{Zr}$ or $\mathrm{TiO}_{2}$, compared with samples further south (Figure 6). A similar distinction is also shown by covariation of $\mathrm{Sr}$ and $\mathrm{Y}$ in which the northern samples generally have much higher $\mathrm{Sr} / \mathrm{Y}$ and $\mathrm{Sr} / \mathrm{Zr}$ ratios than those further to the south.

[18] The covariation of incompatible element ratios, which are not significantly affected by low-pressure basaltic crystallization, summarizes 

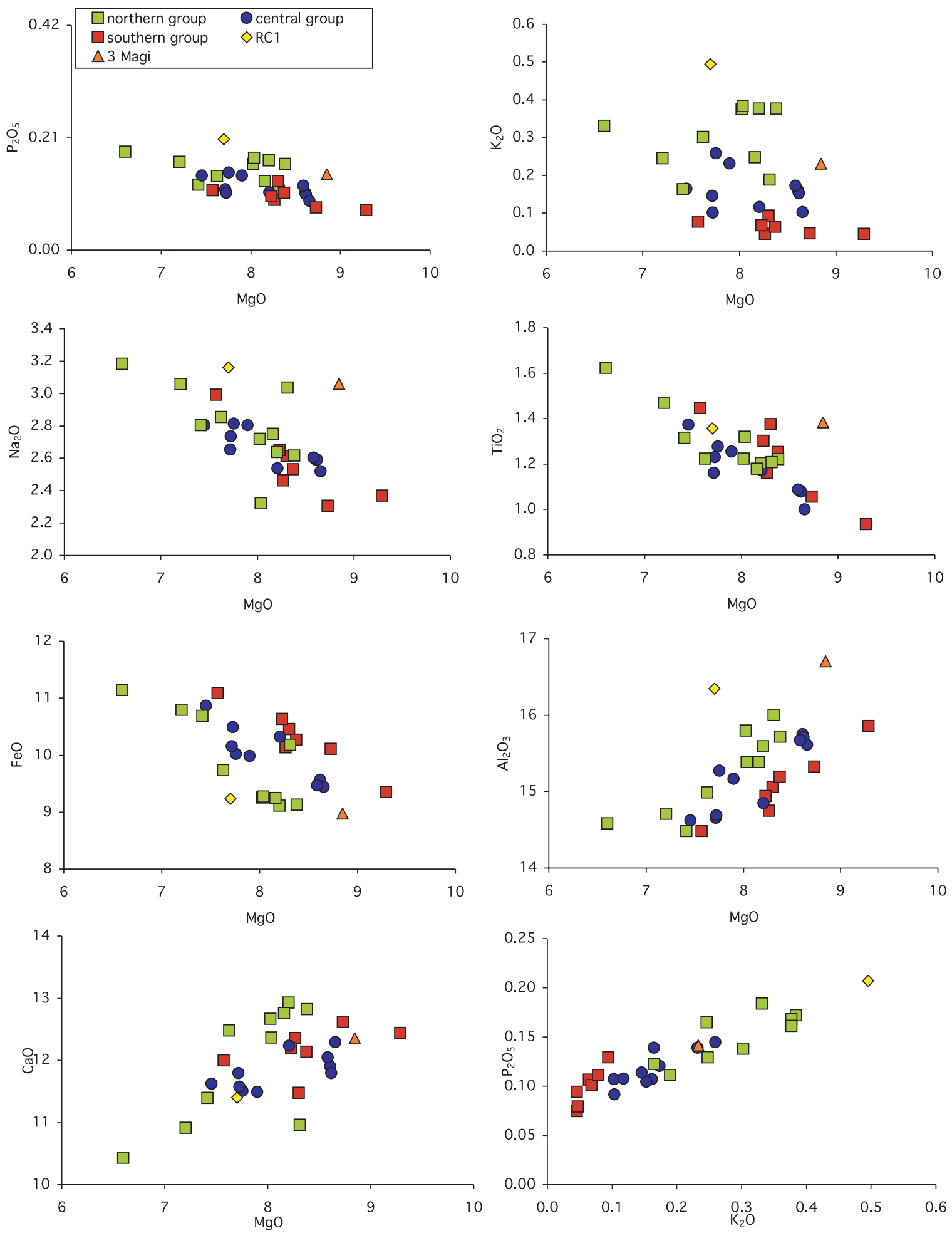

Figure 2. Major elements versus MgO. All analyses are in weight percent, measured as dry weight and determined by electron microprobe on unaltered glass sections. See main body of text for analytical explanation and Table 1 for data. 

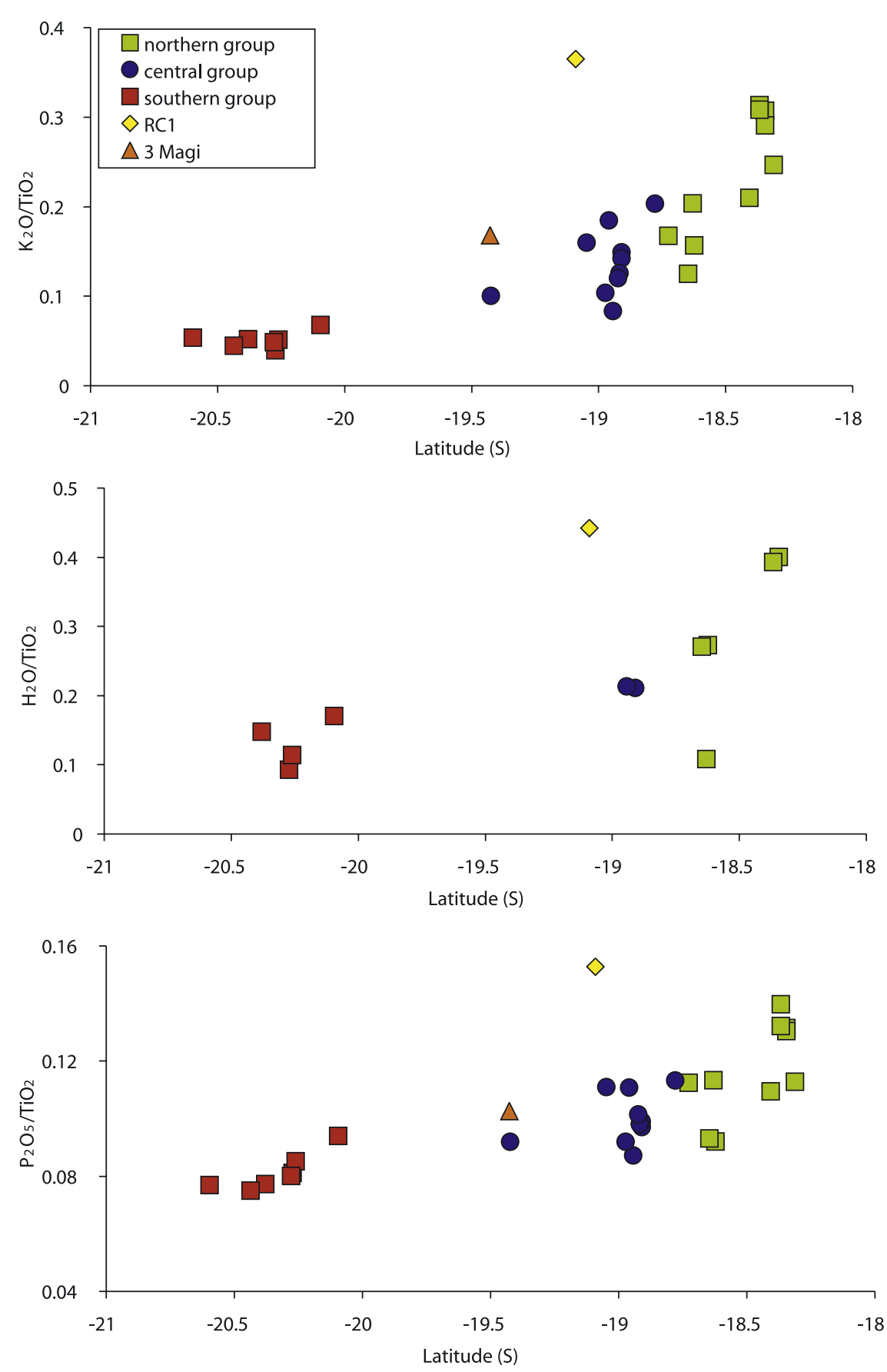

Figure 3a. $\mathrm{K}_{2} \mathrm{O}, \mathrm{H}_{2} \mathrm{O}$, and $\mathrm{P}_{2} \mathrm{O}_{5}$ versus latitude (i.e., distance along the ridge). Each degree of latitude is approximately $110 \mathrm{~km}$. Major elements determined by electron microprobe; water determined by FTIR (see main body of text for explanation).

the differences between CIR groups (Figure 7). The southern samples have low $\mathrm{Zr} / \mathrm{Y}, \mathrm{Sr} / \mathrm{Y}$ and $\mathrm{Ba} / \mathrm{Nb}$ whereas those further north have high $\mathrm{Zr} / \mathrm{Y}$, $\mathrm{Sr} / \mathrm{Y}$ and $\mathrm{Ba} / \mathrm{Nb}$. Samples from the central group have low $\mathrm{Zr} / \mathrm{Y}$, moderate $\mathrm{Sr} / \mathrm{Y}$ and high $\mathrm{Ba} / \mathrm{Nb}$. This geography is also shown by covariation of $\mathrm{Nb} / \mathrm{Sr}$ versus $\mathrm{La} / \mathrm{Sm}$, in which the southern and central groups form a trend with lower $\mathrm{La} / \mathrm{Sm}$ for a given $\mathrm{Nb} / \mathrm{Sr}$ compared with the northern group. Thus the CIR lavas appear to have several primary compositional characteristics: progressive enrichment northward of incompatible element concentrations and ratios, including water; and for the most northerly samples, an additional enrichment 

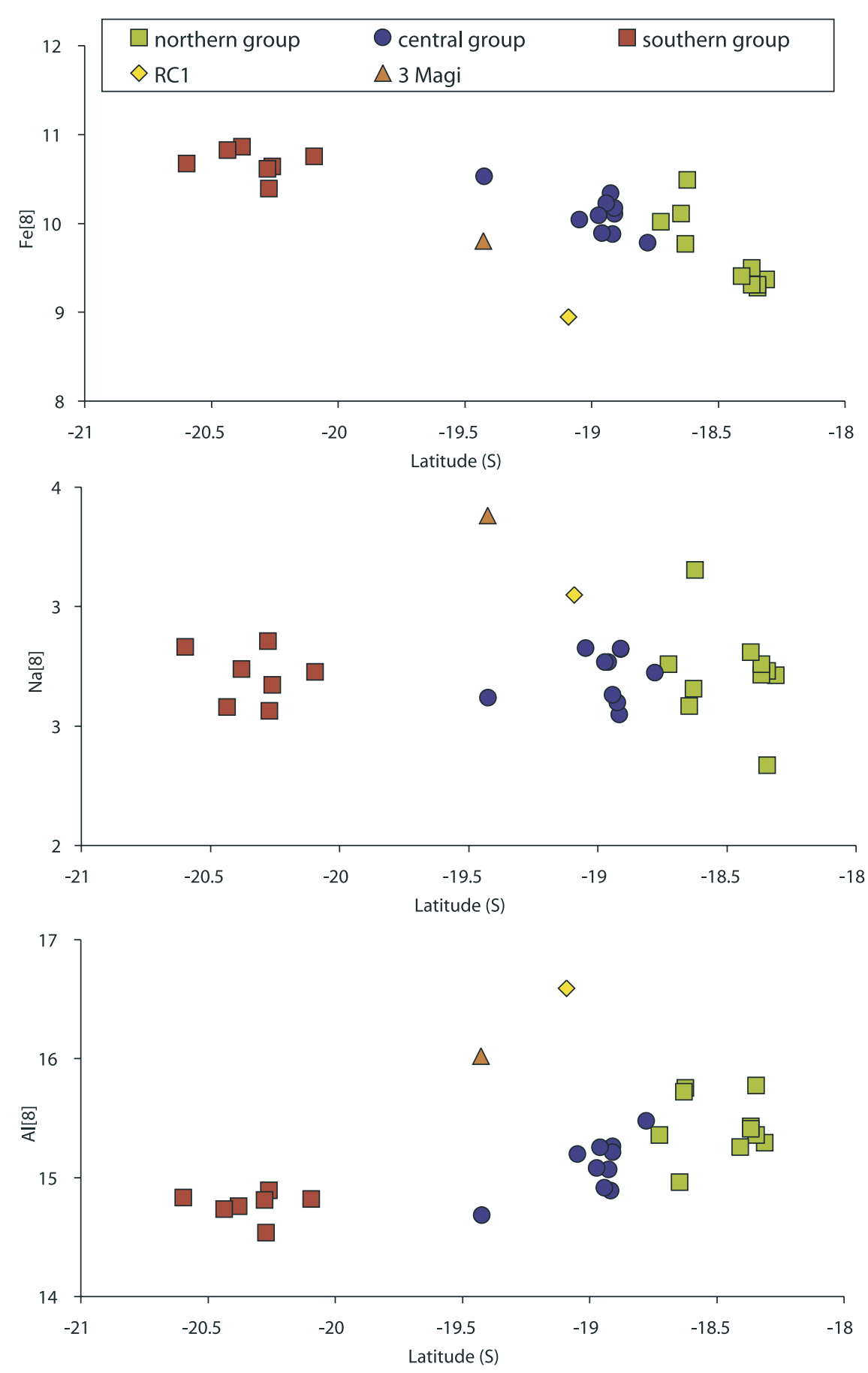

Figure 3b. $\mathrm{NaO}, \mathrm{FeO}$, and $\mathrm{Al}_{2} \mathrm{O}_{3}$ normalized to $\mathrm{MgO}$ [8\%], denoted by the term [8]. Normalization is made by regressing along a linear gradient defined by the relationship of each element $(\mathrm{X})$ versus $\mathrm{MgO}$, calculated from the southern group of CIR samples. These samples are chosen since they are the most MORB-like and define coherent linear arrays in X versus MgO space. The normalized values indicate either differences in parental melt composition, variation in crystallization histories, or a mixture of both. The decrease in apparent $\mathrm{Fe}_{[8]}$ and increase in apparent $\mathrm{Al}_{[8]}$ with latitude northward (i.e., approximating to distance along the ridge) is compatible with plagioclase saturation occurring at progressively higher $\mathrm{MgO}$ as a result of increasing magmatic water content. 


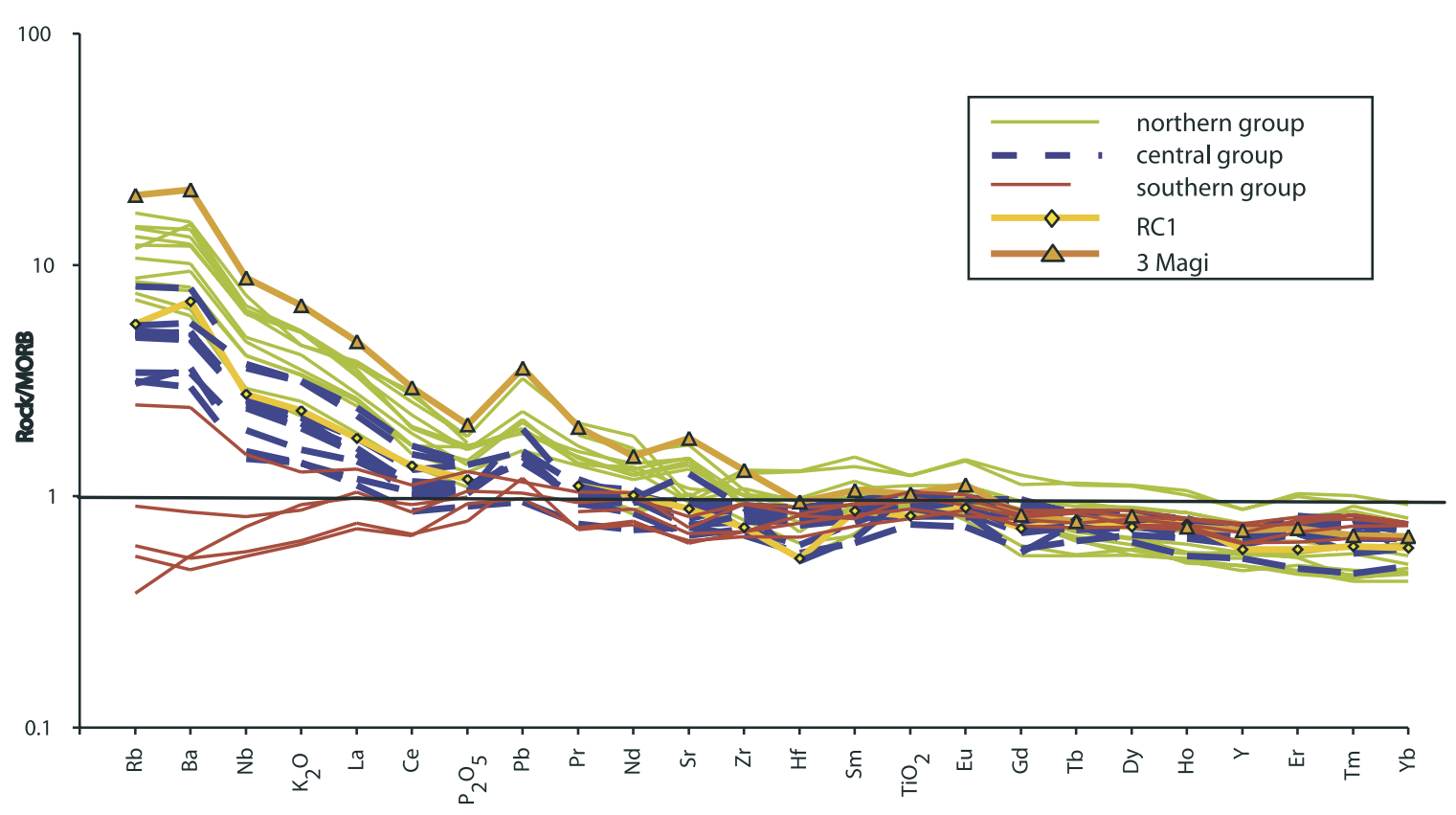

Figure 4a. Concentration of incompatible elements, arranged from left to right by decreasing bulk partition coefficient in MORB, and normalized against MORB [from Hofmann, 1988]. The red dashed lines are samples forming the southern group, the blue solid lines are samples forming the central group, and the green solid lines are samples forming the northern group. The orange line with triangles represents the sample from the off-axis 3 Magi ridges (D5-2), and the yellow solid line and diamonds ( $\mathrm{RC} 1)$ is a sample from the edge of the axial valley.

in strontium and depletion in yttrium and heavy rare earth elements (REE).

\section{Discussion}

\subsection{Fractional Crystallization}

[19] A crystal fractionation model that mass balance the effects of removal of equilibrium phases olivine, plagioclase and pyroxene (starting with phenocrysts analyzed from the southern sample, $\mathrm{RC} 14$ ), generally reproduces the range of major element compositions shown by the southern group. However, it does not fit the central or northern group trends (Figure 8) that are more closely reproduced by the thermodynamic-based fractional crystallization models (PMELTS [Ghiorso et al., 2002]), when 0.1 wt.\% magmatic water is included at a magmatic pressure of $3 \mathrm{kbar}$ (see caption to Figure 8 for details about each of individual model conditions). A high-pressure fractionation model (e.g., at $10 \mathrm{kbar}$ ) fails to reproduce any of the trends, and is hence the least applicable to the CIR. Together, the low-pressure fractionation models suggest the CIR basalts derive from parental magmas with similar major element composi- tions, but with an increase in water content from south to north. The range of fractionation, from the most primitive to the most evolved sample, is up to $25 \%$.

[20] Crystal fractionation in basaltic magmas is particularly sensitive to the effects of increased magmatic water content on delaying crystallization of plagioclase until lower values of $\mathrm{MgO}$ [Shen and Forsyth, 1995; Danyushevsky, 2001]. This results in higher values of $\mathrm{Al}_{2} \mathrm{O}_{3}$ and $\mathrm{CaO}$, and lower $\mathrm{FeO}$, for a given concentration of $\mathrm{MgO}$; an effect shown by the northern group which has a positive correlation between apparent $\mathrm{Al}_{[8]}$ and $\mathrm{H}_{2} \mathrm{O} / \mathrm{TiO}_{2}$ (Figure 9). Lower values of apparent $\mathrm{Fe}_{[8]}$ also correlate with higher values of $\mathrm{Al}_{[8]}$ (Figure 10). This suggests the low $\mathrm{Fe}_{[8]}$ (also characteristic of the northern samples) is likely to be a result of the effects of delayed plagioclase crystallization, rather than a decrease in the average depth of melting (as suggested by the global correlation between apparent $\mathrm{Fe}_{[8]}$, ridge depth and crustal thickness [Klein and Langmuir, 1987]). Alternatively, there may be a decrease in iron concentration in the source that fortuitously coincides with an increase in water content and the suppression of plagioclase fractionation. 

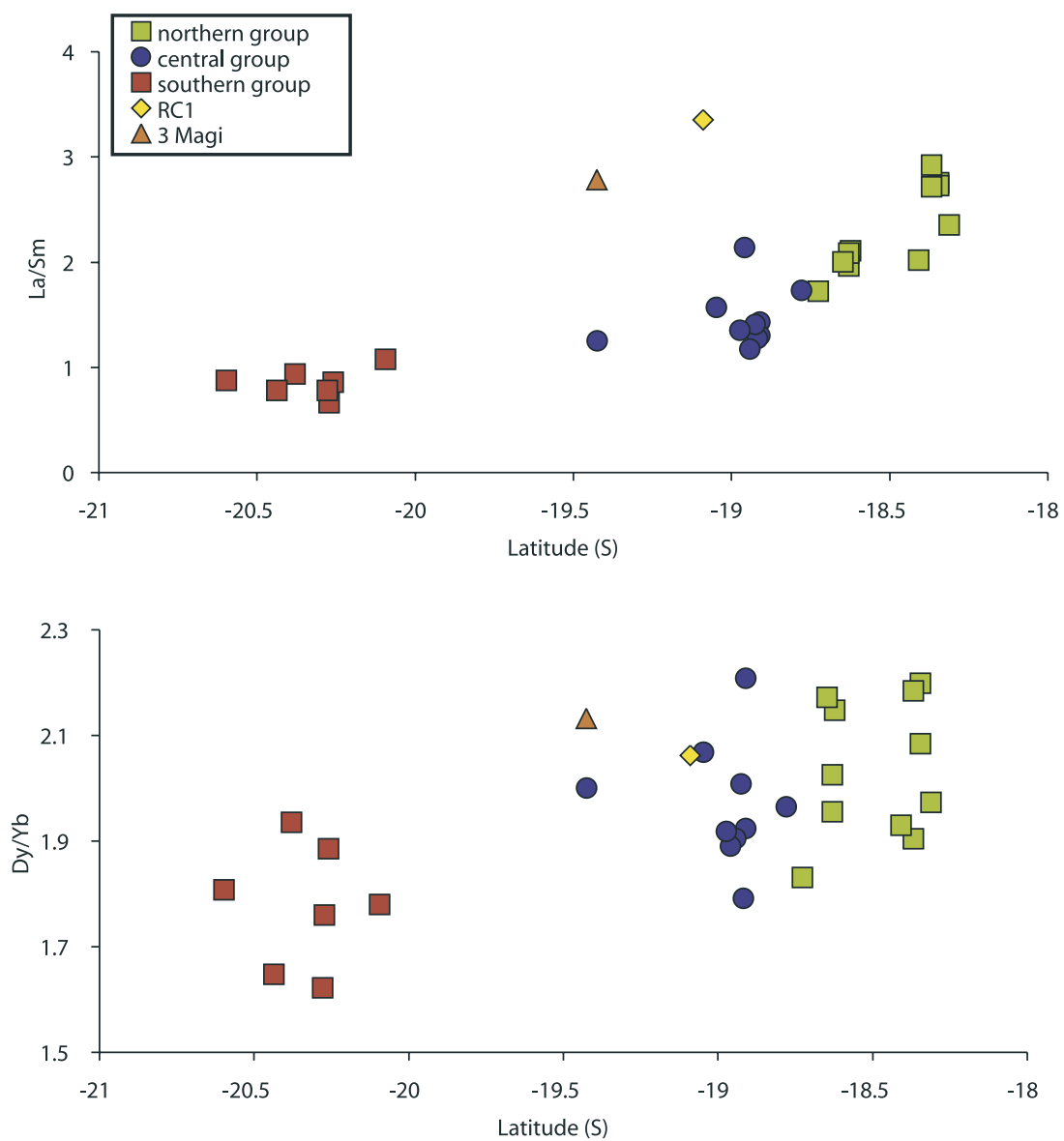

Figure 4b. Rare earth element ratios versus latitude (i.e., distance along ridge). The increase in La/Sm suggests an increase in light rare earth element enrichment of the parental melts. The general increase in Dy/Yb suggests an increase in the proportion of residual garnet during lherzolite mantle melting. Rare earth element data are from laser ablation ICP-MS analysis of glassy material (see text for full explanation).

However, this requires an exact correlation between iron depletion and water enrichment. While this cannot be ruled out, it would require a remarkable coincidence.

\subsection{Source Melting and Composition}

[21] The relatively shallow depth of the CIR immediately to the south of the Marie Celeste fracture zone suggests the presence of thicker crust (in response to an increase in melt production), lowdensity mantle (possibly resulting from higher mantle temperatures), or a combination of both. However, the relatively high abundances and ratios of incompatible elements for these northern segments imply either a decrease in melt fraction, or an increase in enrichment of the mantle source. An increase in mantle temperature or water content (lowering the mantle solidus [Hirth and Kohlstedt, 1996] will both increase the initial depth of mantle melting and its mean melt production [Klein and Langmuir, 1987; McKenzie and Bickle, 1988]. In contrast, the northward decrease in $\mathrm{Fe}_{[8]}$ suggests melting decreases in depth. Yet this is probably an artifact of greater magmatic water contents as discussed above. An alternative indicator of the initial depth of mantle melting is the increased effect of residual garnet with greater pressure. Since garnet retains the heavy rare earth elements (REE) in preference to middle and light REE [Shibata et al., 1979; Hauri et al., 1994; Harte and Kirkley, 1997; Blundy et al., 1998], its presence during mantle melting is indicated by an increase in $\mathrm{Dy} / \mathrm{Yb}$ ratio. For the CIR, $\mathrm{Dy} / \mathrm{Yb}$ generally increases with distance northward (Figure 4b). Alternatively, some high-pressure amphiboles and phlogopite also retain heavy REE. But these minerals also have high partition coefficients for potassium [Adam et al., 1993], resulting in decreasing $\mathrm{K}_{2} \mathrm{O} / \mathrm{TiO}_{2}$ with increasing 

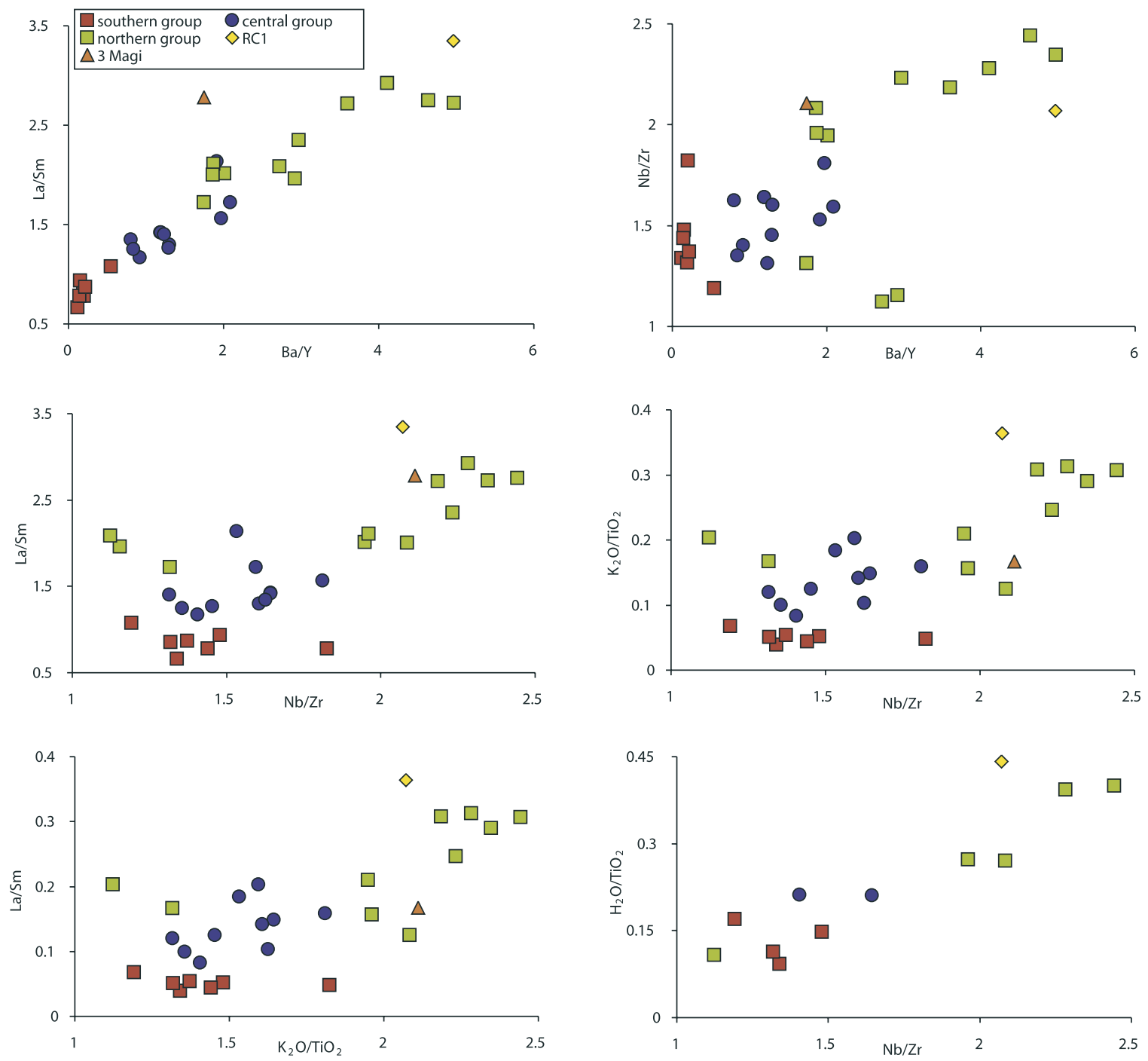

Figure 5. Correlations between ratios of incompatible trace elements: the northern group is consistently more enriched in strongly incompatible elements relative to moderately incompatible ones, compared with the central and southern groups, respectively. Sample RC1 is often one of the most enriched samples, while the 3 Magi sample (D5-2) is moderately enriched. The trace element enrichment coincides with a similar enrichment in potassium and water. Incompatible element ratios are not strongly affected by fractional crystallization, and instead reflect changes in parental melt composition.

$\mathrm{Dy} / \mathrm{Yb}$. This is not the case for the CIR basalts. Thus the increase of both $\mathrm{Dy} / \mathrm{Yb}$ and $\mathrm{K}_{2} \mathrm{O} / \mathrm{TiO}_{2}$ for the northern samples suggests garnet involvement during melting and hence melting starts deeper in the north than farther to the south.

\subsection{Causes of Enrichment: Lower Melt Fraction Versus Mantle Composition}

[22] In addition to increasing the depth of initial mantle melting and the melt production, Asimow and Langmuir [2003] argued that an increase in mantle water content could also cause an expan- sion of the deeper, low melt-fraction region of the subridge melting zone. As a result, aggregated fractional melts from a wetter mantle will be relatively enriched in incompatible element rich, small melt fractions, compared with those aggregates from a dryer mantle.

[23] Recent studies of the Galapagos Spreading Center (GSC) by Cushman et al. [2004] have also modeled the effects of hydrous melting, under active mantle-upwelling conditions. By selecting some of the more incompatible major elements ( $\mathrm{Ca}, \mathrm{Na}, \mathrm{K}, \mathrm{Ti})$, increasing the upwelling rate for 

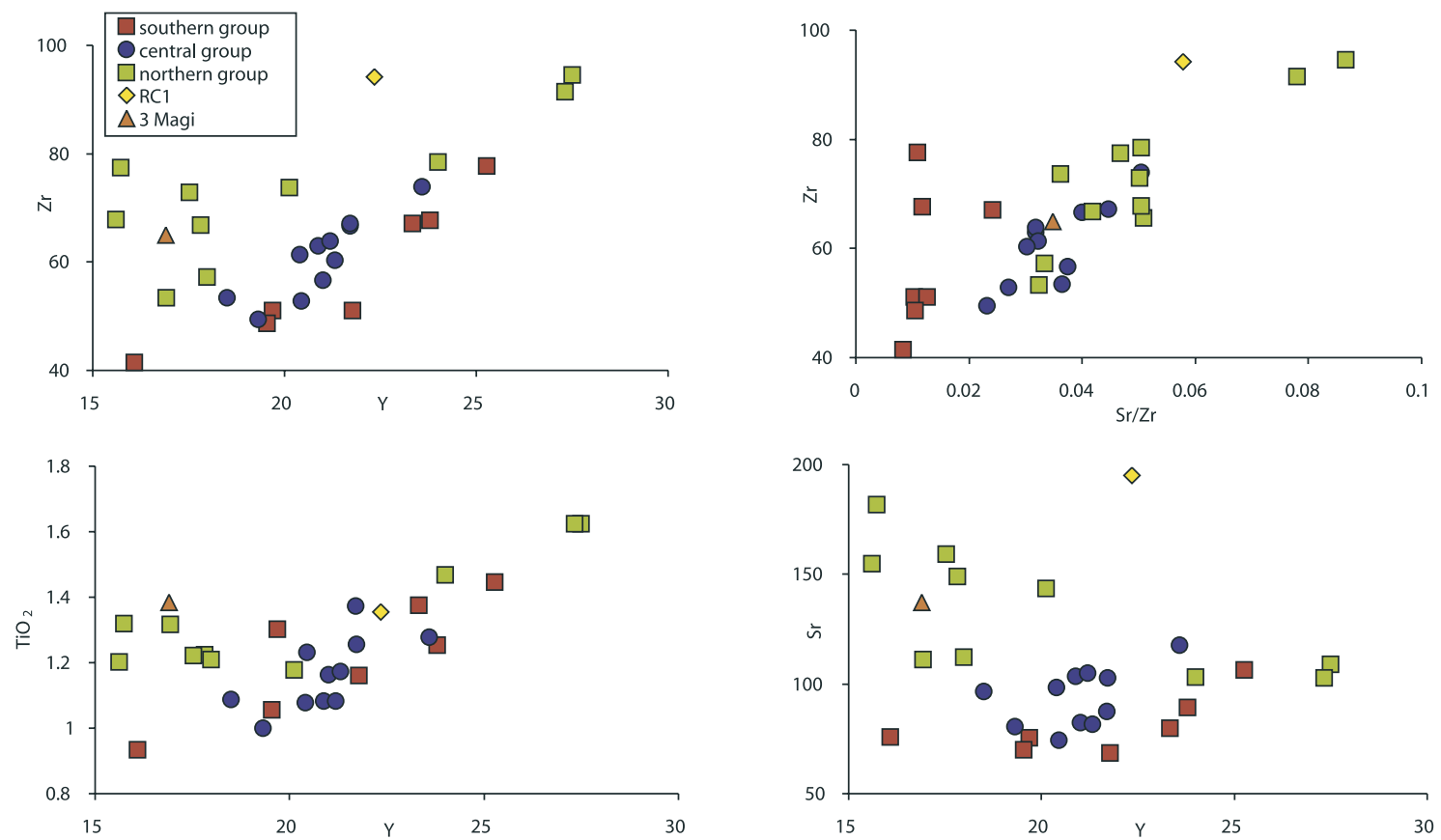

Figure 6. Covariation of trace element concentrations (ppm, except $\mathrm{TiO}_{2}$ in wt.\%) and ratios indicate relative depletion in $\mathrm{Y}$, and enrichment in $\mathrm{Sr}$, for the northern group and 3 Magi sample compared with the central and southern groups. Compared with the 3 Magi sample, RC1 has the greatest Sr enrichment (see text for description of analytical methods).

the hydrous lower half of the mantle melting column relative to its upper half by up to a factor of 5 , and by reducing its decompression melt yield by up to a factor of 8 , they are able to account for both anomalously thick crust and major element enrichment of MORB along the GSC. In effect, the hydrous melting models of both Cushman et al. [2004] and Asimow et al. [2004] invoke the addition of large volumes of small melt fraction to the normal bulk aggregate MORB. This results in geochemical mixing trajectories between normal MORB and a range of very small incremental melt fractions. For these models to be universal, the mixing schemes must work for all elements, especially the strongly incompatible trace elements that are more sensitive to variations in melt fraction than the major elements.

[24] To test whether hydrous mantle melting alone might cause the incompatible element enrichment along the CIR, we have modeled the effects of adding variable volumes of small fractions to aggregated MORB mantle melts. The results are shown in Figure 10, where they are compared with the CIR basalts. Our modeling uses constant partition coefficients for the trace elements, but varies the mantle mineralogy (and hence elemental bulk partition coefficients) according to pressure and extent of melting (see caption to Figure 8 for details). We do not assume any dynamic mantle upwelling scheme, nor vary adiabatic melt production rates for different depths within the mantle melt column, as these are unnecessary. Instead, if hydrous melting results in the addition of small melt fractions (e.g., as proposed by Cushman et al. [2004] and others), then the aggregated melts will lie somewhere within a geochemical envelope defined by the aggregated melting trend for normal MORB, and mixing trajectories between normal MORB and the first incremental melt composition.

[25] Figure 10 shows the results of our model, compared with the compositions of CIR samples. On all diagrams, the southern group (e.g., the normal MORB-like samples) is reproduced by an aggregated melt following $\sim 8 \%$ incremental mantle melting of either a garnet-lherzolite or spinellherzolite mantle source (see McKenzie and Bickle [1988] for starting source parameters and Table 3 for mineral-liquid partition coefficients). In $\mathrm{Zr} / \mathrm{Y}$ versus $\mathrm{La} / \mathrm{Sm}$ space, the CIR samples lie close to mixing hyperbolae for the pooled $8 \%$ melt fraction and the $0.1 \%$ and $0.2 \%$ fractional melts from a garnet-lherzolite source. However, this is not consistent on other diagrams. For example, in $\mathrm{Zr} / \mathrm{Y}$ versus $\mathrm{Sm} / \mathrm{Yb}$ space the CIR samples lie outside 

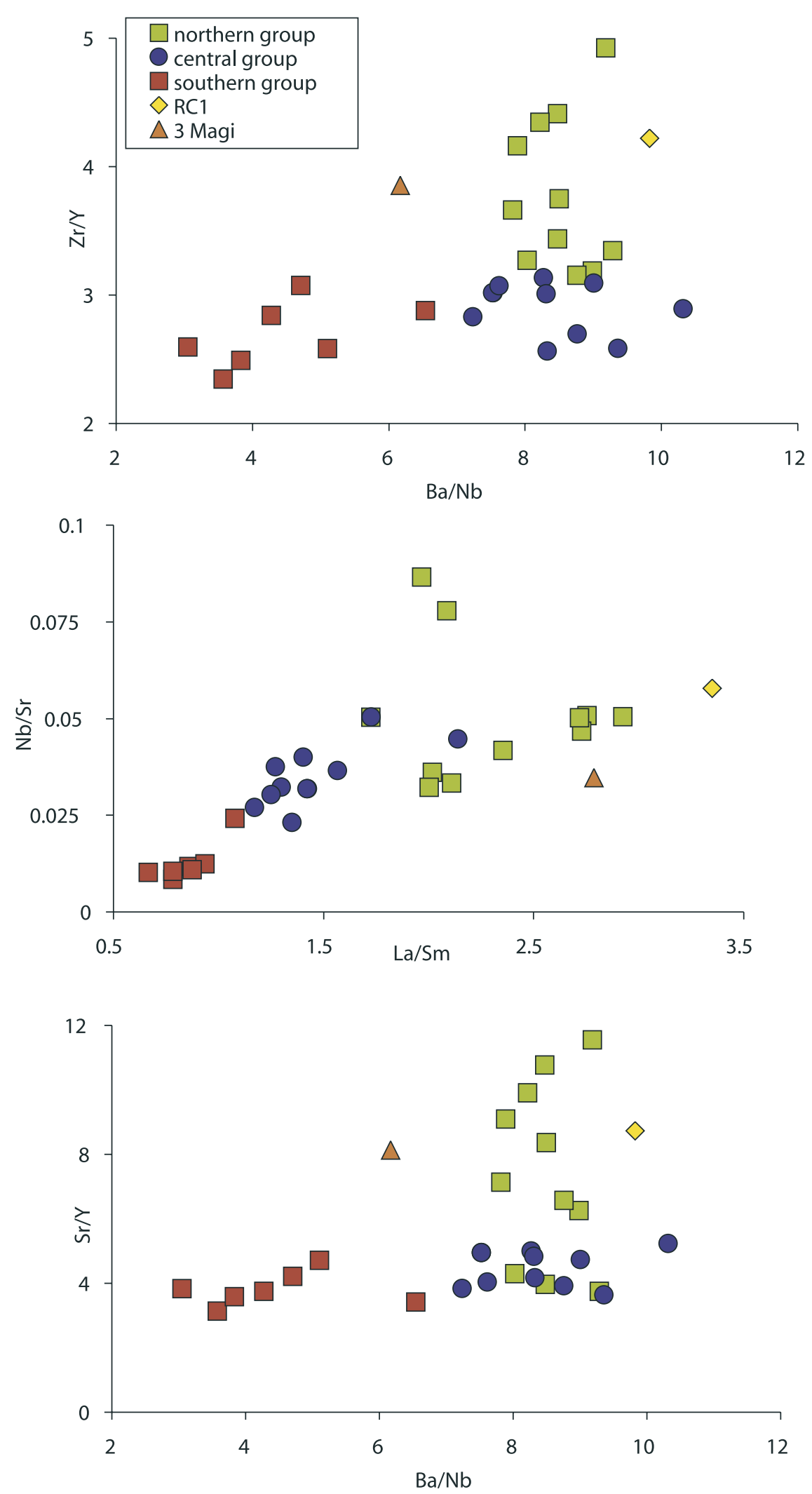

Figure 7. Incompatible trace element ratios separate the data into three arbitrary, yet consistent, groups. The northern group generally has higher $\mathrm{Sr}$ and lower $\mathrm{Y}$ and $\mathrm{Yb}$ relative to the other groups. Sample $\mathrm{RC} 1$ and 3 Magi resemble the northern group. 

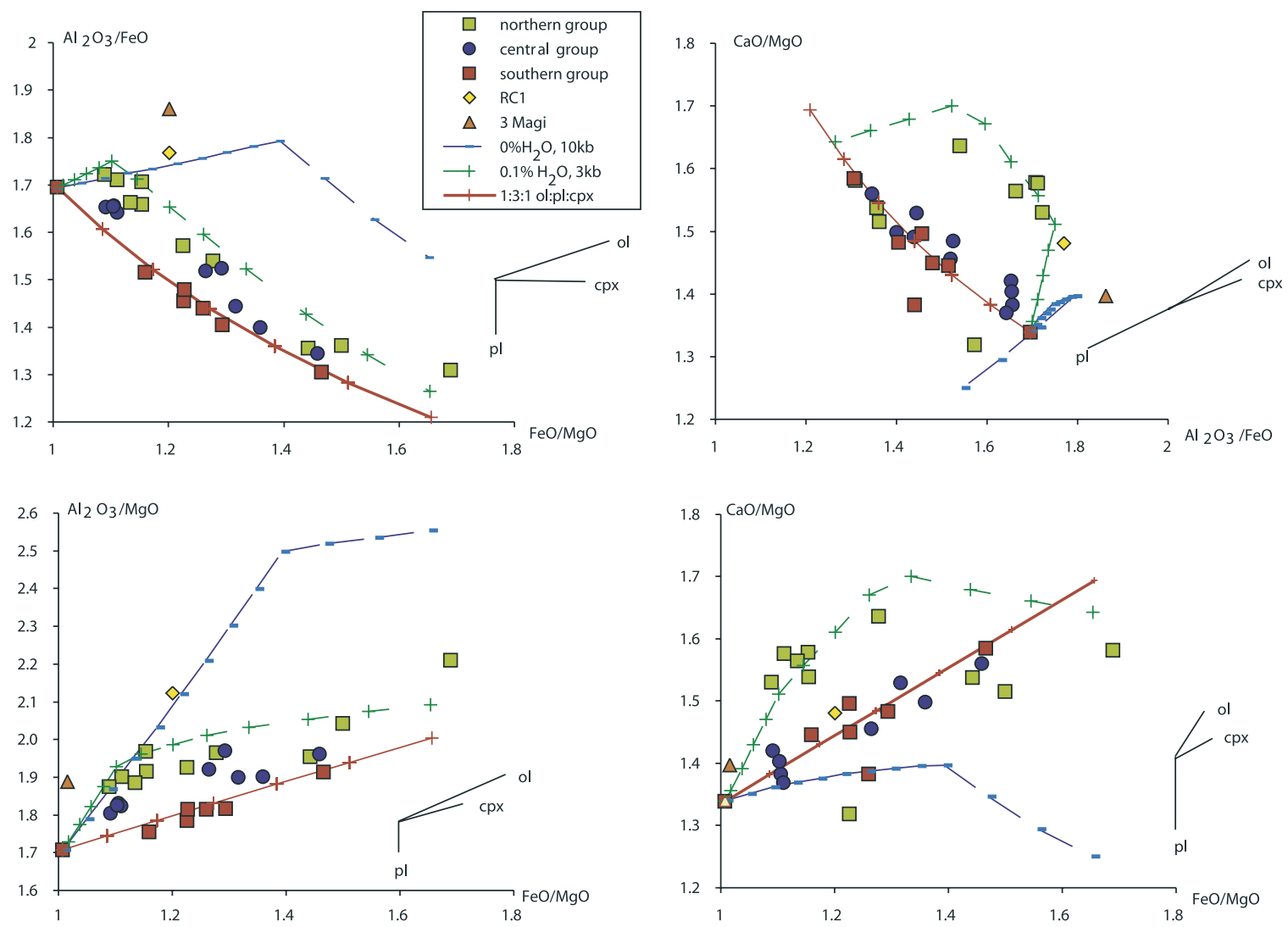

Figure 8. Modal fractional crystallization models generally reproduce the range in compositions shown by the CIR basalts following $\sim 25 \%$ crystallization. The solid red line is the liquid line of descent (LLD) predicted by a model that removes phases in fixed proportions of 1:3:1 for ol:plag:cpx. The initial phase compositions are those analyzed and in equilibrium with the starting basalt (RC14). Phase compositions and residual melt compositions are recalculated at each $1 \%$ step of fractional crystallization. Ticks mark every $5 \%$ of fractionation. The dashed green line is the LLD for fractional crystallization predicted by the PMELTS model, starting with basalt composition RC14, assuming QFM, a pressure of $3 \mathrm{kbar}$, and $0.1 \mathrm{wt} . \% \mathrm{H}_{2} \mathrm{O}$. The dashed dark blue line was modeled assuming QFM, a pressure of $10 \mathrm{kbar}$, and $0 \mathrm{wt} \% \mathrm{H}_{2} \mathrm{O}$. Ticks mark steps of $\sim 2 \%$ crystallization. While the fixed proportion model reproduces the trend of the southern group of samples, the PMELTS model that includes an increase in magmatic water content is better at reproducing the northern group. The central group of sample lies between the two models. The northern group has a trend that indicates the effect of delayed plagioclase fractionation, in accordance with an increase in water content. The high-pressure model does not reproduce any of the observed trends. The low-pressure models indicate a further fractionation of up to $25 \%$, starting from RC14, for the CIR as a whole. The vectors (solid black arrows) indicate the effects of fractional removal of individual phases (ol., olivine; cpx., clinopyroxene; pl., plagioclase). The plots suggest the northern group is displaced away from the central and southern groups in the direction of plagioclase accumulation. This is consistent with the notion that the northern group is affected by plagioclase fractionation at a lower $\mathrm{MgO}$ concentration than the other groups (e.g., as a result of an increase in magmatic water content).

the melting/mixing envelope and hence cannot be explained by a scheme that mixes small melt fractions with aggregated MORB-like melts.

[26] Thus, while the CIR array cannot be reproduced by the types of hydrous melting models that result in bulk addition of voluminous small melt fractions to a pooled MORB, it is consistently reproduced by simple bulk mixing between a depleted and an enriched basaltic end-member
(Figure 10). This indicates significant variation in the composition for the mantle beneath the CIR rather than variations in melting conditions alone. Furthermore, this variation appears to be the result of mantle mixing between an enriched component and a relatively depleted one, similar to the mixing schemes for ridge-hot spot interaction, first proposed by Schilling et al. [1983], and similar to the one proposed by Mahoney et al. [1989] for the Réunion-CIR couplet. However, not all of the CIR 

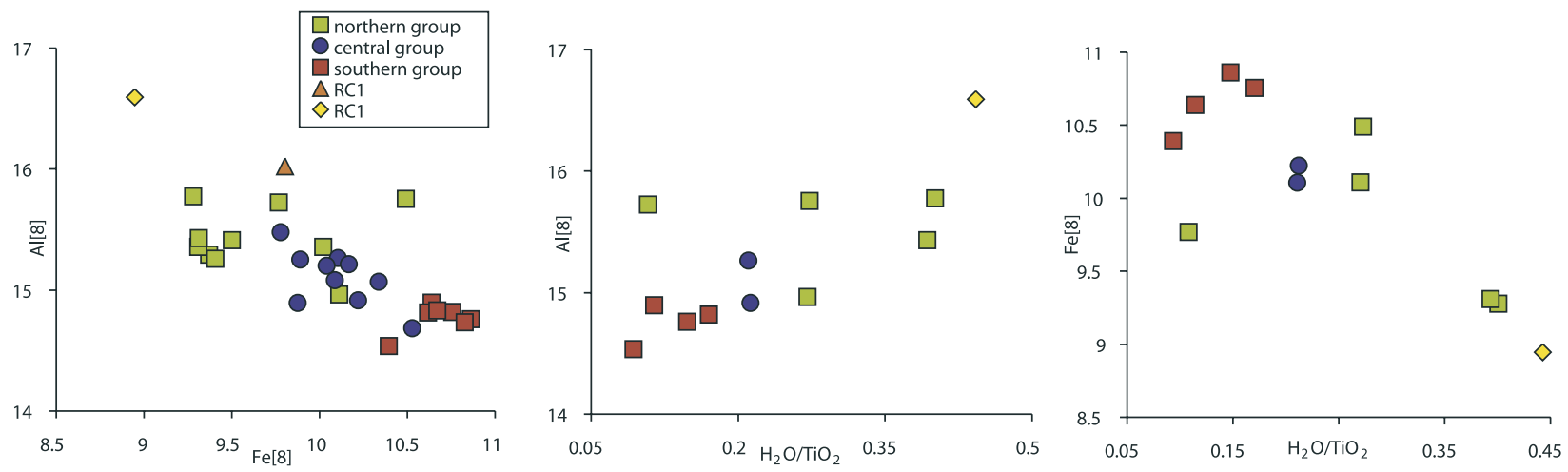

Figure 9. $\mathrm{Al}_{[8]}, \mathrm{Fe}_{[8]}$, and $\mathrm{H}_{2} \mathrm{O} / \mathrm{TiO}_{2}$. Water contents are determined by FTIR spectral analysis. The values of $\mathrm{Al}_{[8]}$ and $\mathrm{Fe}_{[8]}$ are derived by regressing the $\mathrm{Al}_{2} \mathrm{O}_{3}$ and $\mathrm{FeO}$ concentrations in the basalts along a linear slope $\left(\mathrm{from} \mathrm{Al}_{2} \mathrm{O}_{3}\right.$ and $\mathrm{FeO}$ versus $\mathrm{MgO}$ ) that passes through the southern group of samples (i.e., those that are the most MORB-like) to a common value of $\mathrm{MgO}$ (chosen as $8 \mathrm{wt} . \%$ ). This regression approximates the liquid line of descent (LLD) during low-pressure crystallization for the southern group (see Figure 8). For the central and northern groups, variation in $\mathrm{Al}_{[8]}, \mathrm{Fe}_{[8]}$, and $\mathrm{H}_{2} \mathrm{O} / \mathrm{TiO}_{2}$ indicates differences in LLD. For example, the inverse correlation between $\mathrm{Al}_{[8]}$ and $\mathrm{Fe}_{[8]}$ and their correlation with $\mathrm{H}_{2} \mathrm{O} / \mathrm{TiO}_{2}$ are consistent with the effects of delayed plagioclase crystallization, caused by an increase in magmatic water content.

samples conform to a simple mixing scheme: some are displaced relative to others. For example, the 3 Magi and $\mathrm{RC} 1$ samples are displaced toward lower $\mathrm{Sm} / \mathrm{Yb}$ and $\mathrm{Zr} / \mathrm{Y}$, compared to the northern group, suggesting they are less affected by residual mantle garnet. Similarly, variation in the mean melt fraction probably affects other samples, and is a likely cause for some of the dispersion of the data away from the mixing line. In summary, the mantle beneath the CIR has variable amounts of an incompatible element enriched component, whose concentration increases northward. In addition, there appears to be a general increase in the depth of initial mantle melting toward the north.

\subsection{Relationship of Enrichment to the Réunion Hot Spot}

[27] The limited number of published $\mathrm{Pb}, \mathrm{Sr}, \mathrm{Nd}$ and $\mathrm{He}$ isotope ratios for the CIR suggest the area immediately south of the Marie Celeste fracture zone is enriched by mantle similar in isotopic composition to the modern Réunion hot spot [Mahoney et al., 1989]. On diagrams that use highly incompatible trace element ratios, the CIR data lie close to binary mixing trends (Figure 11) between depleted MORB-like compositions, characteristic of the southern CIR group, and basalts from La Réunion island and its flank [Upton and Wadsworth, 1972; Ludden, 1978; Fisk et al., 1988; Albarède et al., 1997; Fretzdorff and Haase, 2002]. Our most depleted southern sample is slightly more incompatible element depleted than plume-free northern Mid-Atlantic Ridge N-MORB, and lies at the most depleted end of the Southwest Indian Ridge (SWIR) range, including the Rodrigues Triple Junction [Mahoney et al., 1989; Meyzen et al., 2003]. Our enriched northern group overlaps the depleted end of the La Réunion field, but has slightly lower ratios involving the heavy REE and yttrium, compared with the island's basalts. The latter suggests a lesser garnet effect and hence shallower mantle melting for our northern CIR basalts compared with those from La Réunion. Two samples in particular stand out from the mixing trends shown in Figure 11: RC1 (the highly enriched flank sample) and the 3 Magi sample (D5-2, the off-axis en echelon ridge sample). Both samples are displaced from the mixing lines toward lower $\mathrm{Sm} / \mathrm{Yb}$ and higher $\mathrm{La} / \mathrm{Sm}$, suggesting they are derived from a lower mean melt fraction and shallower initial depth of melting compared with the northern CIR lavas, to which they are most closely related. This interpretation fits the location of these samples, with RC1 and the 3 Magi both from off-axis sites. If erupted on thicker lithosphere under cooler mantle conditions, then both initial melting depth and mean melt fraction are likely to be less than at the ridge axis.

[28] Basalts from our northern group also show differences in composition, compared with those from La Réunion, that are not easily explained by melting or crystallization conditions. For example, the northern CIR group has excess strontium, compared with other incompatible-trace elements 
(a)
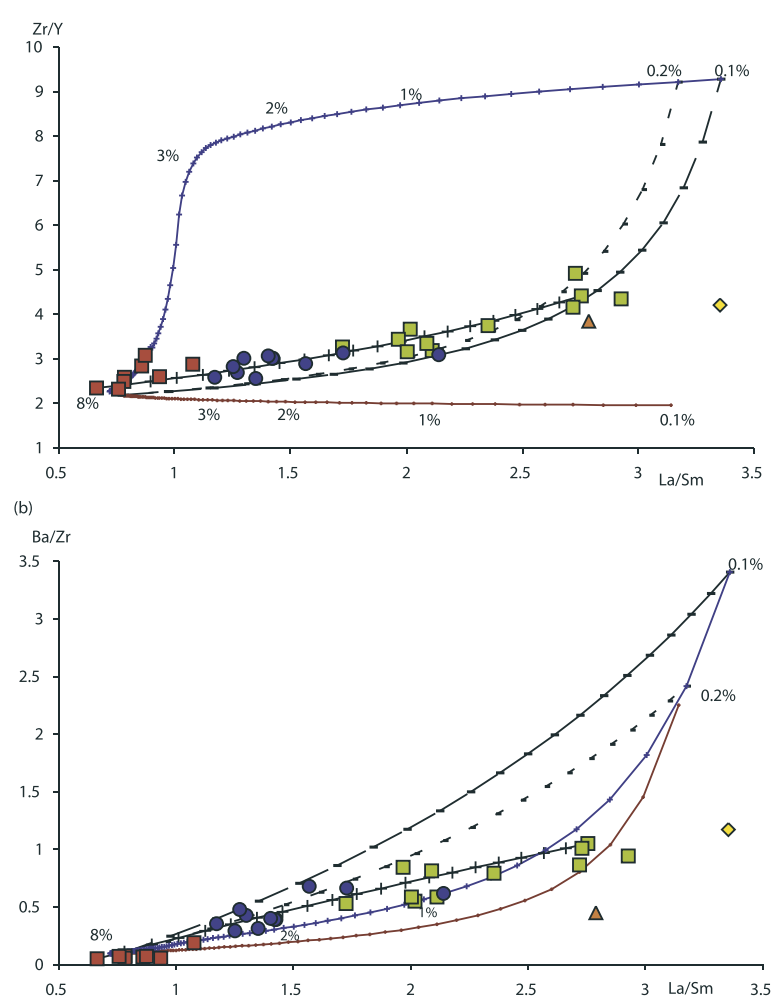

(c)

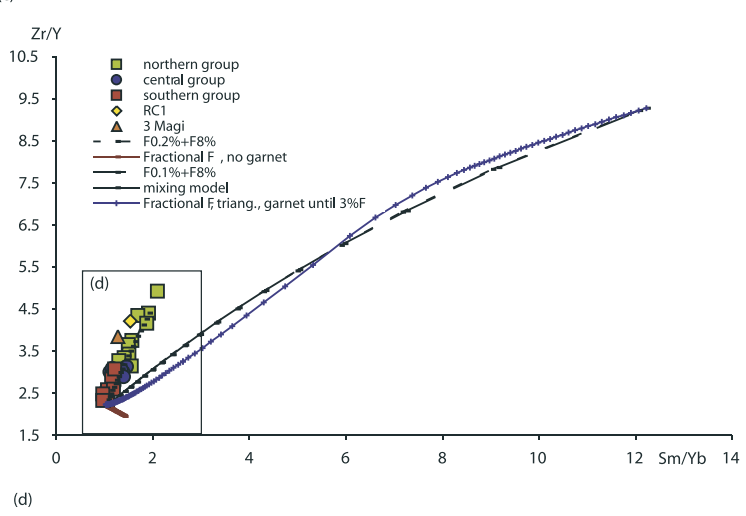

(d)

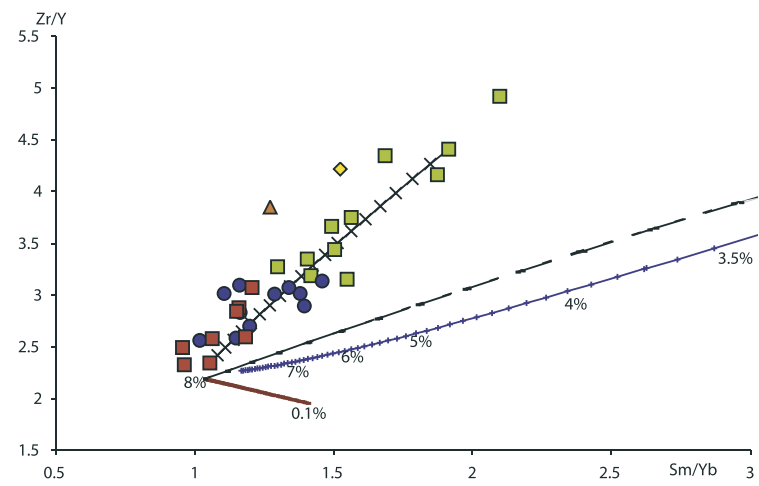

Figure 10. Polybaric melting models of spinel and garnet lherzolite at mantle pressures. Mineral liquid partition coefficients are based on those compiled by McKenzie and Bickle [1988] and McKenzie and O'Nions [1991] with additional ones for selected trace elements from Philpotts and Schnetzler [1970], Hart and Brooks [1974], and Kravuchuk et al. [1981]. Starting phase proportions (taken from McKenzie [1984]) for spinel lherzolite are olivine = 0.575 , clinopyroxene $=0.119$, orthopyroxene $=0.27$, and chrome spinel $=0.033$. Starting proportions for garnet lherzolite are olivine $=0.598$, clinopyroxene $=0.076$, orthopyroxene $=0.211$, and garnet $=0.115$. Modal changes during fusion are clinopyroxene consumed at $0.3 \%$ by volume for every $0.1 \%$ melting and olivine and orthopyroxene consumed at $0.1 \%$ by volume for every $0.1 \%$ melting. Melt compositions are calculated as total aggregated melt fractions following fractional incremental melting in $0.1 \%$ increments. Melting with residual garnet is similarly calculated but with garnet content declining to zero over a $3 \%$ melting interval. The melting lines are ticked every $0.1 \%$ and extend to a total of $8 \%$ fusion. The mixing model lines are ticked every $0.5 \%$ and assume liquid mixing on a volumetric basis. If the CIR samples are a product of variation in the contribution of small melt fractions within the mantle melting zone (e.g., as suggested for hydrous melting [Cushman et al., 2004]), then they must fall within the envelope defined by the mantle melting curves and mixing between pooled MORB and the first incremental melt. For example, the dashed and dotted black lines indicate mixing between an unenriched sample (RC23) and a small melt fraction generated after $0.1 \%$ and $0.2 \%$ fusion of garnet lherzolite, respectively. While the CIR samples lie on such a mixing line in Figure 10a, they are not consistent in other trace element-ratio space. In Figures 10c and 10d, the CIR samples fall outside the envelope altogether. In contrast, the solid black line shows bulk volumetric mixing between the most depleted (RC23) and enriched (RC20) samples and consistently reproduces the CIR trend. The models serve to illustrate that the incompatible element enrichment shown by the CIR basalts is not the result singularly of either: varying degrees of melting, the involvement of residual garnet in the mantle, or the addition of large volumes of a very small melt fraction to a larger pooled melt (e.g., the effects of hydrous melting suggested by Cushman et al. [2004]). Instead, the observed enrichment is consistently reproduced by volumetric mixing of melts represented by two end-members: one that is enriched and one that is depleted in selected incompatible trace elements. These endmembers therefore are most likely to reflect actual variations in mantle source composition (e.g., as proposed by Mahoney et al. [1989]), rather than changes in mantle melting conditions.

(Figures 6 and 7). If this positive strontium anomaly were a function of delayed plagioclase crystallization, it would also correlate with a positive europium anomaly (since europium has a prefer- entially higher partition coefficient in plagioclase than its neighboring middle rare earth elements [Kravuchuk et al., 1981]). However, a plot of $\mathrm{Sr}$ versus $\mathrm{Eu} / \mathrm{Eu}^{*}$ (Figure 12) shows no such correla- 
Table 3. Partition Coefficients (kD) and Modal Phase Proportions Used as Starting Conditions of the Mantle Melting Models Cited in the Text and Shown in Figure $10^{\mathrm{a}}$

\begin{tabular}{|c|c|c|c|c|c|c|c|c|}
\hline & Ol. & Plag. & Cpx. & Opx. & Spinel & Amph. & Gnt. & $\mathrm{D}$ \\
\hline \multicolumn{9}{|c|}{ Spinel-lherzolite } \\
\hline Proportion & 0.578 & 0 & 0.119 & 0.27 & 0 & 0 & 0 & \\
\hline \multicolumn{9}{|l|}{$\mathrm{kD}$} \\
\hline $\mathrm{Sr}$ & 0.0002 & 2.000 & 0.130 & 0.007 & & 0.12 & 0.0011 & 0.019 \\
\hline $\mathrm{Rb}$ & 0.00018 & 0.03 & 0.13 & 0.0006 & $1.00 \mathrm{E}-03$ & 0.19 & 0.0007 & 0.016 \\
\hline $\mathrm{Ti}$ & 0.02 & 0.04 & 0.18 & 0.1 & 0.15 & 1.5 & 0.28 & 0.087 \\
\hline $\mathrm{Zr}$ & 0.01 & 0.01 & 0.1 & 0.03 & & 0.5 & 0.32 & 0.034 \\
\hline $\mathrm{Ba}$ & 0.0003 & 0.33 & 0.0005 & 0.001 & 0.001 & 0.76 & 0.0005 & 0.001 \\
\hline $\mathrm{Nb}$ & 0.005 & 0.01 & 0.02 & 0.005 & & 0.8 & 0.07 & 0.008 \\
\hline Y & 0.005 & 0.031 & 0.2 & 0.005 & 0.01 & 1 & 2.11 & 0.029 \\
\hline $\mathrm{Nd}$ & 0.001 & 0.14 & 0.21 & 0.0068 & 0.01 & 0.44 & 0.087 & 0.029 \\
\hline $\mathrm{La}$ & 0.0004 & 0.27 & 0.054 & 0.002 & 0.01 & 0.17 & 0.01 & 0.008 \\
\hline $\mathrm{Sm}$ & 0.0013 & 0.11 & 0.26 & 0.01 & 0.01 & 0.76 & 0.087 & 0.037 \\
\hline Dy & 0.0017 & 0.055 & 0.33 & 0.022 & 0.01 & 0.78 & 1.06 & 0.052 \\
\hline $\mathrm{Yb}$ & 0.0015 & 0.031 & 0.28 & 0.049 & 0.01 & 0.59 & 4.03 & 0.061 \\
\hline \multicolumn{9}{|c|}{ Garnet-lherzolite } \\
\hline $\begin{array}{l}\text { Proportion } \\
\mathrm{kD}\end{array}$ & 0.598 & 0 & 0.076 & 0.211 & 0 & 0 & 0.115 & \\
\hline $\mathrm{Sr}$ & 0.0002 & 2.000 & 0.130 & 0.007 & & 0.12 & 0.0011 & 0.013 \\
\hline $\mathrm{Rb}$ & 0.00018 & 0.03 & 0.13 & 0.0006 & $1.00 \mathrm{E}-03$ & 0.19 & 0.0007 & 0.010 \\
\hline $\mathrm{Ti}$ & 0.02 & 0.04 & 0.18 & 0.1 & 0.15 & 1.5 & 0.28 & 0.100 \\
\hline $\mathrm{Zr}$ & 0.01 & 0.01 & 0.1 & 0.03 & & 0.5 & 0.32 & 0.063 \\
\hline $\mathrm{Ba}$ & 0.0003 & 0.33 & 0.0005 & 0.001 & 0.001 & 0.76 & 0.0005 & 0.001 \\
\hline $\mathrm{Nb}$ & 0.005 & 0.01 & 0.02 & 0.005 & & 0.8 & 0.07 & 0.015 \\
\hline $\mathrm{Y}$ & 0.005 & 0.031 & 0.2 & 0.005 & 0.01 & 1 & 2.11 & 0.263 \\
\hline $\mathrm{Nd}$ & 0.001 & 0.14 & 0.21 & 0.0068 & 0.01 & 0.44 & 0.087 & 0.029 \\
\hline $\mathrm{La}$ & 0.0004 & 0.27 & 0.054 & 0.002 & 0.01 & 0.17 & 0.01 & 0.006 \\
\hline $\mathrm{Sm}$ & 0.0013 & 0.11 & 0.26 & 0.01 & 0.01 & 0.76 & 0.087 & 0.035 \\
\hline Dy & 0.0017 & 0.055 & 0.33 & 0.022 & 0.01 & 0.78 & 1.06 & 0.157 \\
\hline $\mathrm{Yb}$ & 0.0015 & 0.031 & 0.28 & 0.049 & 0.01 & 0.59 & 4.03 & 0.506 \\
\hline
\end{tabular}

\footnotetext{
${ }^{a}$ Mineral liquid partition coefficients are from compilations by McKenzie and Bickle [1988] and McKenzie and O'Nions [1991] with additional trace element kD from Philpotts and Schnetzler [1970], Hart and Brooks [1974], and Kravuchuk et al. [1981]. Starting modal proportions are after McKenzie [1984].
}

tion, indicating that plagioclase crystallization is unlikely to affect the strontium enrichment in the northern group. Alternatively, there may be a strontium-rich component in the source. However, the absence of any europium anomaly means it is equally unlikely that this component is, or was, plagioclase bearing (e.g., a relict gabbro), or caused by shallow mantle melting in the plagioclase stability field. Whatever its source, the strontium enrichment also correlates closely with $\mathrm{H}_{2} \mathrm{O} / \mathrm{TiO}_{2}$ (Figure 12), raising the possibility that the enriched component affecting our northern CIR group also contains a strontium-rich, hydrous fluid.

\subsection{Links With La Réunion}

[29] Basalts from the CIR show compositions resembling those from the flanks of La Réunion. But the hot spot, currently $1100 \mathrm{~km}$ to the west of the CIR, last coincided with the spreading ridge at $38 \mathrm{Ma}$. Since then, $\sim 1600 \mathrm{~km}$ of new oceanic crust have been generated at the CIR which has migrated north-eastward away from the hot spot [Royer et al., 1997]. If the enrichment of the CIR lavas is inherited from mantle contaminated by the Réunion hot spot at $38 \mathrm{Ma}$, then this contaminated mantle must have been thick enough, or embedded to sufficient depth, to survive upwelling and melting during the generation of $\sim 1600 \mathrm{~km}$ of new oceanic crust. Alternatively, the enriched mantle may be supplied from La Réunion. In this case, it probably has the form of an eastward-flowing tongue of material that migrates toward the CIR against the motion of the lithosphere (Figure 13).

[30] This tongue of enriched asthenosphere still retains a high proportion of incompatible element enrichment, as well as the volatile compound $\mathrm{H}_{2} \mathrm{O}$, and hence has not been significantly depleted by melting on route to the CIR. However, the initial depth of melting is shallower under the CIR than beneath La Réunion, suggesting that the tongue of 

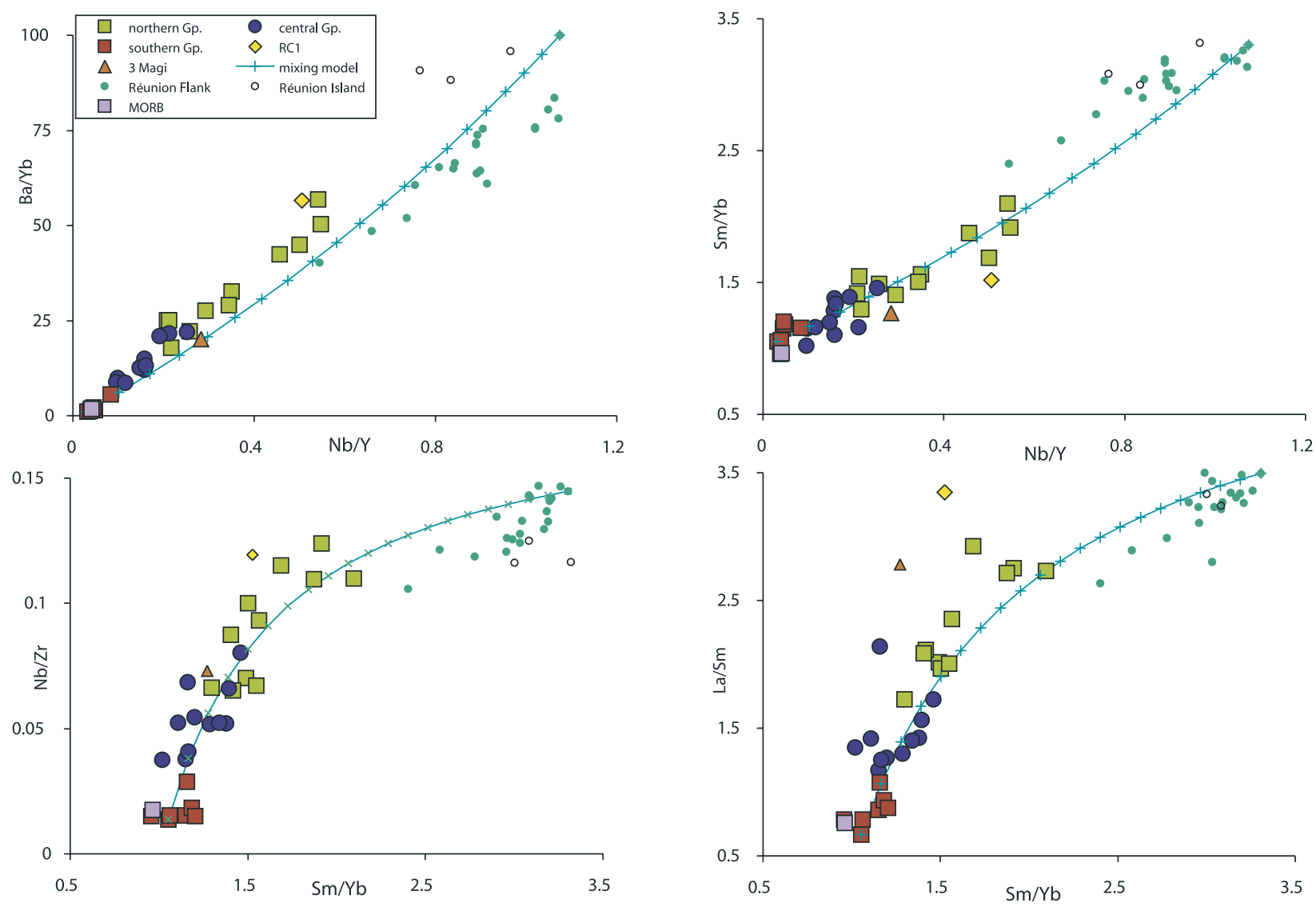

Figure 11. Mixing between basalts from La Réunion and the southern CIR. The CIR range falls on a mixing line between the southern CIR group and the more incompatible element enriched members of the La Réunion flank basalts [Fretzdorff and Haase, 2002]. La Réunion basalts [Upton and Wadsworth, 1972; Ludden, 1978; Fisk et al., 1988; Albarède et al., 1997] generally have slightly lower Yb and Y than the CIR, indicating a greater garnet effect during mantle melting and hence initial melting at a greater depth compared with the CIR. Differences between the absolute proportions of depleted CIR and enriched Réunion end-members for individual samples, represented on the different ratio plots, reflect slight variations in melt fraction among the CIR and Réunion samples. Ticks on the mixing lines correspond to increments of $5 \%$.

hot spot mantle cools as it migrates toward the CIR. Since the Marie Celeste fracture zone forms a boundary to the enrichment along the CIR [Mahoney et al., 1989], and the enrichment decreases progressively south along the ridge away from the fracture zone, it seems more likely that mixing between the hot spot mantle and normal MORB mantle occurs beneath the CIR rather than en route. If the tongue of hot spot mantle is driven toward the spreading ridge by flowing upslope along the base of the lithospheric toward the ridge axis (e.g., as proposed by Sleep [1996]), then it probably spreads along the CIR as a southwardthinning wedge that overlies the normal MORB mantle. Judging from the distribution of enrichment along the CIR, such a wedge of enriched mantle thins south along the ridge for at least 250 $\mathrm{km}$. Assuming a minimum thickness for the wedge of $80 \mathrm{~km}$ close to the Marie Celeste fracture zone (i.e., just deep enough to supply initial mantle melts from the garnet lherzolite stability field), linear thinning of the wedge over $250 \mathrm{~km}$, and a steady state flux from the Réunion hot spot (at a constant full spreading rate for the CIR of $43 \mathrm{~mm}$ per year), yields a flux of hot spot asthenosphere migrating to the CIR from La Réunion at a rate of $\sim 0.4 \mathrm{~km}^{3}$ per yr, or $\sim 13 \mathrm{~m}^{3} \mathrm{~s}^{-1}$.

\section{Conclusions}

[31] Over a distance of about $250 \mathrm{~km}$ northward toward the Marie Celeste fracture zone, lavas erupted along the rift axis of the CIR shows a trend from normal MORB to enriched basalts, with 

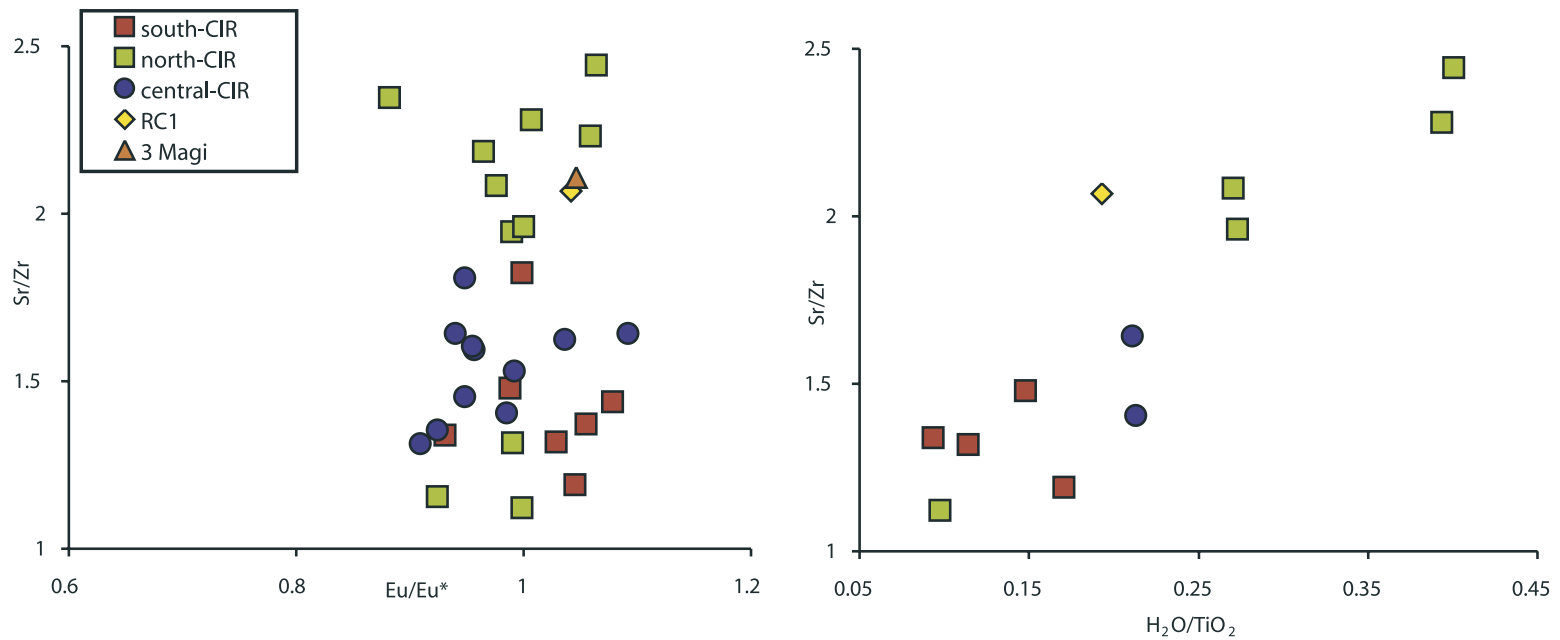

Figure 12. Compared with the other CIR groups, the northern group is relatively enriched in $\mathrm{Sr}$ and $\mathrm{H}_{2} \mathrm{O}$ relative to other incompatible trace elements. However, the strontium enrichment is independent of variation in $\mathrm{Eu} / \mathrm{Eu}$ (where $\mathrm{Eu}^{*}$ is $\operatorname{sqrt}([\mathrm{Sm}] \times[\mathrm{Gd}])$, i.e., the predicted value of $\left.\mathrm{Eu}\right)$, suggesting it is not an affect of plagioclase assimilation or melting of a relict mantle plagioclase.

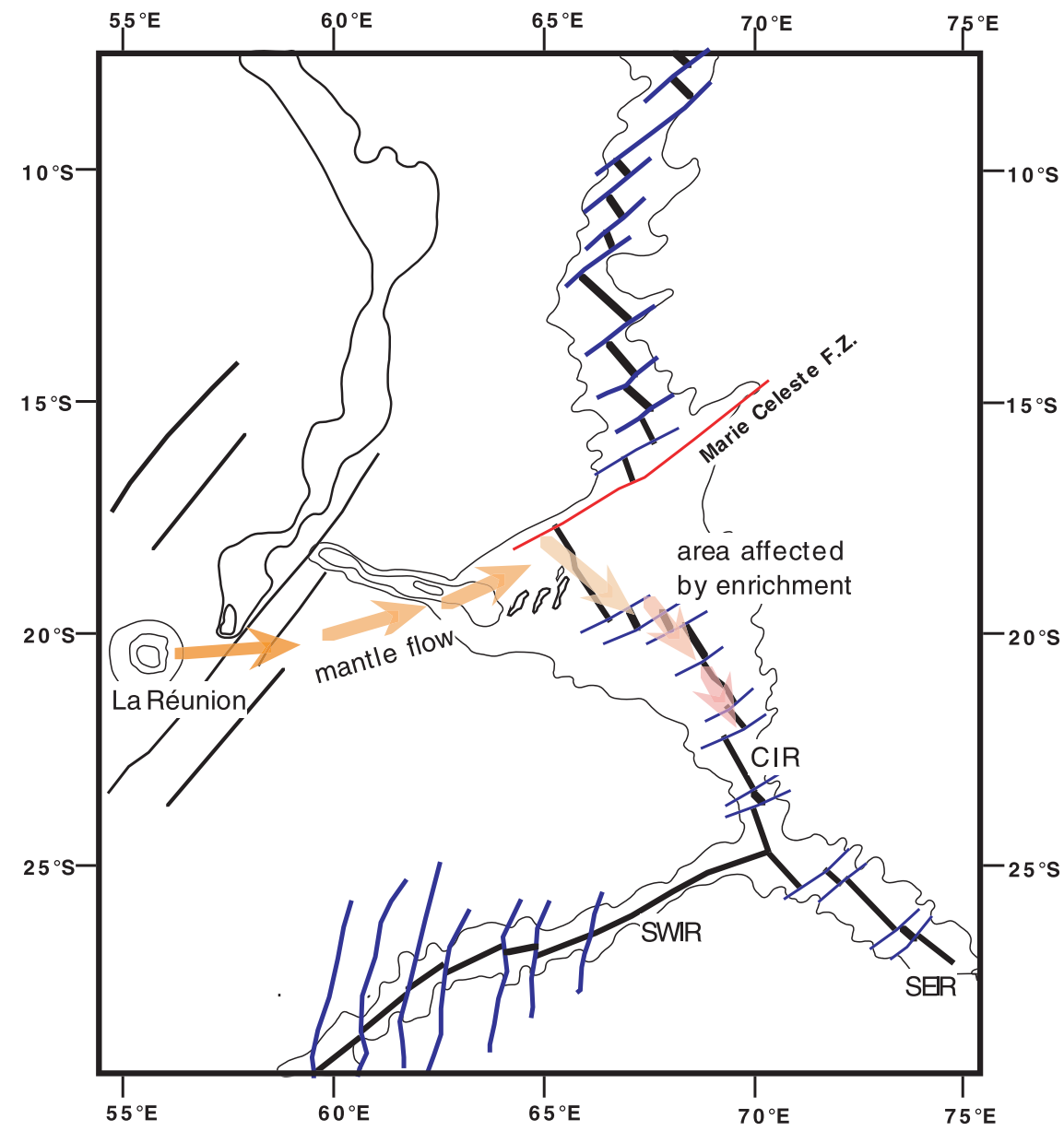

Figure 13. Cartoon showing the inferred direction of migration of enriched mantle from the Réunion hot spot toward the CIR. As it flows east and then south along the CIR, the enriched mantle mixes with depleted MORB mantle, producing the observed geochemical gradient. 
elevated incompatible element concentrations and ratios (including elevated $\mathrm{H}_{2} \mathrm{O}$, lower $\mathrm{Fe}_{[8]}$, and higher $\mathrm{Al}_{[8]}$ ). In addition, the northernmost samples are relatively enriched in strontium and have heavy REE to middle REE depletion. To the south, the samples resemble normal MORB. These form the depleted end of a mixing line that includes the northern basalts at its enriched end and whose compositions overlap the field for La Réunion Island tholeiites. After testing to what extent the enrichment is a function of varying conditions of crystal fractionation, plagioclase assimilation or mantle melting (including hydrous melting), we conclude it is caused by mixing between depleted asthenosphere (yielding normal MORB in the south) and mantle from the Réunion hot spot. This requires hot spot asthenosphere to migrate eastward away from La Réunion and toward the CIR, against the motion of the lithosphere, over a distance of $\sim 1100 \mathrm{~km}$. While the initial depth of mantle melting increases northward along the CIR, it remains shallower than beneath La Réunion, suggesting that the eastward flowing hot spot mantle cools during its migration toward the ridge. However, the hot spot mantle that reaches the CIR retains its incompatible element content and volatile hydrous phase, and hence is not depleted by melting en route. Thus the influence of Réunion hot spot mantle on the CIR remains compelling evidence for active migration of hot spot material from La Réunion to the spreading ridge, over a distance of $\sim 1100 \mathrm{~km}$.

\section{Acknowledgments}

[32] We are indebted to the officers, crew, and technical engineers of the RRS Charles Darwin for their seamanship and tenacity to "see the job through" during cruise CD127. We also thank the reviewers, Dave Christie and Jim Mahoney, for their helpful comments on the earlier draft of this manuscript. The work was funded by the Natural Environment Research Council (NERC) grant to the Crustal Processes Group at the Southampton Oceanography Centre, UK.

\section{References}

Adam, J., T. H. Green, and S. H. Sie (1993), Proton microprobe determined partitioning of $\mathrm{Rb}, \mathrm{Sr}, \mathrm{Ba}, \mathrm{Y}, \mathrm{Zr}, \mathrm{Nb}$ and $\mathrm{Ta}$ between experimentally produced amphiboles and silica melts with variable F content, Chem. Geol., 109, 29-49.

Albarède, F., B. Luais, G. Fitton, M. Semet, E. Kaminski, B. G. J. Upton, P. Bachelery, and J.-L. Cheminé (1997), The geochemical regimes of Piton de la Fournaise volcano (Réunion) during the last 530000 years, J. Petrol., 38, 171-201.

Asimow, P. D., and C. H. Langmuir (2003), The importance of water to oceanic mantle melting regimes, Nature, 42, 815820 .
Asimow, P. D., J. E. Dixon, and C. H. Langmuir (2004), A hydrous melting and fractionation model for mid-ocean ridge basalts: Application to the Mid-Atlantic Ridge near the Azores, Geochem. Geophys. Geosyst., 5, Q01E16, doi:10.1029/2003GC000568.

Basu, A. R., P. R. Renne, D. K. Dasgupta, F. Teichmann, and R. J. Poreda (1993), Early and late alkali igneous pulses and a high-He-3 plume origin for the Deccan Flood Basalts, Science, 261, 902-906.

Baxter, A. N. (1976), Geochemistry and petrogenesis of primitive alkali basalt from Mauritius, Indian Ocean, Geol. Soc. Am. Bull., 87, 1028-1034.

Blondel, Ph., and B. J. Murton (1997), Handbook of Seafloor Sonar Imagery, 314 pp., John Wiley, Hoboken, N. J.

Blundy, J. D., J. A. C. Robinson, and B. J. Wood (1998), Heavy REE are compatible in clinopyroxene on the spinel lherzolite solidus, Earth Planet. Sci. Lett., 160, 493-504.

Courtillot, V., G. Feraud, H. Maluski, D. Vandamme, M. G. Moreau, and J. Besse (1988), Deccan flood basalts and the Cretaceous/Tertiary boundary, Nature, 333, 843-846.

Cox, K. G., and C. J. Hawksworth (1984), Relative contributions of crust and mantle to flood basalts magmatism, Mahabaleshwar area, Deccan Traps, Philos. Trans. R. Soc. London, Ser. A, 310, 627-642.

Cushman, B., J. Sinton, G. Ito, and J. Eaby Dixon (2004), Glass compositions, plume-ridge interaction, and hydrous melting along the Galápagos Spreading Center, $90.5^{\circ} \mathrm{W}$ to $98^{\circ} \mathrm{W}$, Geochem. Geophys. Geosyst., 5, Q08E17, doi:10.1029/2004GC000709.

Danyushevsky, L. V. (2001), The effects of small amounts of $\mathrm{H}_{2} \mathrm{O}$ on crystallisation of mid-ocean ridge and backarc basin magmas, J. Volcanol. Geotherm. Res., 110, 265-280.

DeMets, C., D. E. Gordan, D. F. Argus, and S. Stein (1994), Effects of recent revisions to the geomagnetic reversal timescale on estimates of current plate motions, Geophys. Res. Lett., 21, 2191-2194.

Detrick, R. S., J. M. Sinton, G. Ito, J. P. Canales, M. Behn, T. Blacic, B. Cushman, J. E. Dixon, D. W. Graham, and J. J. Mahoney (2002), Correlated geophysical, geochemical, and volcanological manifestations of plume-ridge interaction along the Galápagos Spreading Center, Geochem. Geophys. Geosyst., 3(10), 8501, doi:10.1029/2002GC000350.

Dixon, J. E., E. Stolper, and J. R. Holloway (1995), An experimental study of water and carbon dioxide solubilities in mid-ocean ridge basaltic liquids. 1. Calibration and solubility models, J. Petrol., 36, 1607-1631.

Duncan, R. A. (1990), The volcanic record of the Réunion hotspot, Proc. Ocean Drill. Program Sci. Results, 115, 3-10.

Duncan, R. A., and D. G. Pyle (1988), Rapid eruption of the Deccan flood basalts at the Cretaceous/Tertiary boundary, Nature, 333, 841-843.

Dyment, J., et al. (1999), The Magofond 2 cruise: A surface and deep tow survey on the past and present Central Indian Ridge, InterRidge News, 8, 25-31.

Feighner, M. A., and M. A. Richards (1995), The fluid dynamics of plume-ridge and plume-plate interactions: An experimental approach, Earth Planet. Sci. Lett., 129, $171-182$.

Fisk, M. R., B. G. J. Upton, C. E. Ford, and W. M. White (1988), Geochemical and experimental study of the genesis of magmas of Réunion Island, Indian Ocean, J. Geophys. Res., 93, 4933-4950.

Fisk, M. R., R. A. Duncan, A. N. Baxter, J. D. Greenough, R. B. Hargraves, and Y. Tatsumi (1989), Réunion hotspot magma chemistry over the past $65 \mathrm{~m}$. y.: Results from Leg 115 of the Ocean Drilling Programme, Geology, 17, 934-937. 
Fretzdorff, S., and K. M. Haase (2002), Geochemistry and petrology of lavas from the submarine flanks of the Réunion Island (western Indian Ocean): Implications for magma genesis and the mantle source, Miner. Petrol., 75, $153-184$

General Bathymetric Chart of the Oceans (GEBCO) (2003), GEBCO Digital Atlas Centenary Edition [CD-ROM], Int. Hydrogr. Organ., Monaco, France.

Ghiorso, M. S., M. M. Hirschmann, P. W. Reiners, and V. C. Kress, III (2002), The pMELTS: A revision of MELTS for improved calculation of phase relations and major element partitioning related to partial melting of the mantle to $3 \mathrm{GPa}$, Geochem. Geophys. Geosyst., 3(5), 1030, doi:10.1029/ $2001 \mathrm{GC} 000217$.

Graham, D., J. Lupton, F. Albarède, and M. Condomines (1990), Extreme temporal homogeneity of helium isotopes at Piton de la Fournaise, Réunion Island, Nature, 347, 545548.

Hart, S. R., and C. Brooks (1974), Clinopyroxene-matrix partitioning of $\mathrm{K}, \mathrm{Rb}, \mathrm{Cs}, \mathrm{Sr}$ and $\mathrm{Ba}$, Geochim. Cosmochim. Acta, 38, 1799-1806.

Harte, B., and M. B. Kirkley (1997), Partitioning of trace elements between clinopyroxene and garnet: Data from mantle eclogites, Chem. Geol., 136, 1-24.

Hauri, E. H., T. P. Wagner, and T. L. Grove (1994), Experimental and natural partitioning of $\mathrm{Th}, \mathrm{U}, \mathrm{Pb}$ and other trace elements between garnet, clinopyroxene and basaltic melts, Chem. Geol., 117, 149-166.

Hirth, G., and D. L. Kohlstedt (1996), Water in the oceanic upper mantle: Implications for rheology, melt extraction and the evolution of the lithosphere, Earth Planet. Sci. Lett., 144, 93-108.

Hofmann, A. W. (1988), Chemical differentiation of the Earth: The relationship between mantle, continental crust and oceanic crust, Earth Planet. Sci. Lett., 90, 297-314.

Ito, G. (2001), Reykjanes Ridge 'V'-shaped ridges originating from a pulsating and dehydrating mantle plume, Nature, 411, 681-684.

Klein, E. M., and C. H. Langmuir (1987), Global correlations of oceanic ridge basalt chemistry with axial depth and crustal thickness, J. Geophys. Res., 92, 8098-8115.

Kravuchuk, I. K., I. Chernysheva, and S. Urosov (1981), Element distribution between plagioclase and groundmass as an indicator for crystallization conditions of the basalts in the southern vent of Tolbachik, Geochem. Int., 17, 18-24.

Ludden, J. N. (1978), Magmatic evolution of the basaltic shield volcanoes of Réunion Island, J. Volcanol. Geotherm. Res., 4, 171-198.

Mahoney, J. L., J. H. Natland, W. M. White, R. Poreda, S. H. Bloomer, R. L. Fisher, and A. N. Baxter (1989), Isotopic and geochemical provinces of the western Indian Ocean spreading centers, J. Geophys. Res., 94, 4033-4052.

Mahoney, J., R. A. Duncan, W. Khan, E. Gnos, and G. R. McCormick (2002), Cretaceous volcanic rocks of the South Tethyan suture zone, Pakistan: Implications for the Reunion hotspot and Deccan Traps, Earth Planet. Sci. Lett., 203, 295-310.

McDougall, I., and F. G. Chamalaun (1969), Isotopic dating and geomagnetic polarity studies on volcanic rocks from Mauritius, Indian Ocean, Geol. Soc. Am. Bull., 80, 14191442.

McKenzie, D. (1984), The generation and compaction of partially molten rock, J. Petrol., 25, 713-765.

McKenzie, D., and M. J. Bickle (1988), The volume and composition of melt generated by extension of the lithosphere, J. Petrol., 29, 625-629.
McKenzie, D., and R. K. O’Nions (1991), Partial melt distributions from inversion of rare earth element concentrations, J. Petrol., 32, 1021-1091.

McKenzie, D., and J. G. Sclater (1971), The evolution of the Indian Ocean since the Late Cretaceous, Geophys. J. R. Astron. Soc., 25, 437-528.

Meyzen, C. M., M. J. Toplis, E. Humler, J. N. Ludden, and C. A. Mével (2003), A discontinuity in mantle composition beneath the southwest Indian ridge, Nature, 421, $731-733$.

Morgan, W. J. (1978), Rodriguez, Darwin, Amsterdam, a second type of hotspot island, J. Geophys. Res., 83, 53555360 .

Morgan, W. J. (1981), Hotspot tracks and the opening of the Atlantic and Indian Oceans, in The Sea, vol. 7, edited by C. Emiliani, pp. 443-487, John Wiley, Hoboken, N. J.

Muller, R. D., Y.-J. Royer, and L. A. Lawver (1993), Revised plate motions relative to the hotspots from combined Atlantic and Indian Ocean hotspot tracks, Geology, 21, $275-278$

Murton, B. J., I. P. Rouse, N. W. Millard, and C. G. Flewellen (1992), Multisensor, deep-towed instrument explores ocean floor, Eos Trans. AGU, 73, 225-228.

Pandya, N., D. W. Muenow, and S. K. Sharma (1992), The effect of bulk composition on the speciation of water in submarine volcanic glass, Geochim. Cosmochim. Acta, 56, $1875-1883$.

Parson, L. M., P. Patriat, R. C. Searle, and A. R. Briais (1993), Segmentation of the Central Indian Ridge between $12^{\circ} 12^{\prime} \mathrm{S}$ and the Indian Ocean Triple Junction, Mar. Geophys. Res., $15,265-282$.

Patriat, P., and J. Achache (1984), India/Asia collision chronology has implications for crustal shortening and driving mechanisms of plates, Nature, 311, 615-621.

Pearce, N. J. G., W. T. Perkins, J. A. Westgate, M. P. Gorton, S. E. Jackson, C. R. Neal, and S. P. Chenery (1997), A compilation of new and published major and trace element data for NIST SRM 610 and NIST SRM 612 glass reference materials, J. Geostand. Geoanal., 21(1), 115-144.

Philpotts, J. A., and C. C. Schnetzler (1970), Phenocrystmatrix partition coefficients for $\mathrm{K}, \mathrm{Rb}, \mathrm{Sr}$, and $\mathrm{Ba}$, with applications to anorthosite basalt genesis, Geochim. Cosmochim. Acta, 34, 307-322.

Royer, J. Y., R. G. Gordon, C. DeMets, and P. R. Vogt (1997), New limits on the motion between India and Australia since chron 5 (11 Ma) and implications for lithospheric deformation in the equatorial Indian Ocean, Geophys. J. Int., 129, $41-53$.

Sandwell, D. T., and W. H. F. Smith (1992), Global marine gravity from ERS-1, Geosat and Seasat reveals new tectonic fabric, Eos Trans. $A G U, 73(43)$, Fall Meet. Suppl., 133.

Schilling, J. G., M. Zajac, R. Evans, T. Johnston, W. White, J. D. Devine, and R. Kingsley (1983), Petrologic and geochemical variations along the Mid-Atlantic Ridge from $29^{\circ} \mathrm{N}$ to $73^{\circ} \mathrm{N}, \mathrm{Am}$. J. Sci., 283, 510-586.

Schlich, R. (1982), The Indian Ocean: Aseismic ridges, spreading centers and oceanic ridges, in The Ocean Basins and Margins, vol. 6, edited by A. E. M. Nairn and F. G. Steheli, pp. 51-147, Springer, New York.

Shen, Y., and D. W. Forsyth (1995), Geochemical constraints on initial and final depths of melting beneath mid-ocean ridges, J. Geophys. Res., 100, 2211-2237.

Shibata, T., G. Thompson, and F. A. Frey (1979), Tholeiitic and alkali basalts from the Mid-Atlantic Ridge at $43^{\circ} \mathrm{N}$, Contrib. Mineral. Petrol., 70, 127-141. 
Sleep, N. H. (1996), Lateral flow of hot spot material ponded at sublithospheric depths, J. Geophys. Res., 101, 28,06528,083 .

Stolper, E. (1982), Water in silicate glasses: An infrared spectroscopic study, Contrib. Mineral. Petrol., 81, 1-17.

Sun, S.-S., R. W. Nesbitt, and Y. A. Sharaskin (1979), Geochemical characteristics of mid-ocean ridge basalts, Earth Planet. Sci. Lett., 44, 119-138.

Upton, B. G. J., and W. J. Wadsworth (1972), Aspects of magmatic evolution on Réunion Island, Philos. Trans. $R$. Soc. London, Ser A, 271, 105-130.

Vogt, P. R. (1971), Asthenospheric motion recorded by the ocean floor south of Iceland, Earth Planet. Sci. Lett., 13, $153-164$.

Vogt, P. R. (1974), The Icelandic Phenomenon: Imprints of hot-spot on the ocean crust, implications for flow beneath plates, in Geodynamics of Iceland and the North Atlantic Area, edited by L. Kristjonsson, pp. 105-126, Springer, New York.
Vogt, P. R., and G. L. Johnson (1972), Seismic reflection survey of an oblique aseismic basement trend on the Reykjanes Ridge, Earth Planet. Sci. Lett., 15, $248-254$

Weinstein, S. A., and P. L. Olson (1989), The proximity of hotspots to convergent and divergent plate boundaries, Geophys. Res. Lett, 16, 433-436.

White, R. S., J. W. Brown, and J. R. Smallwood (1995), The temperature of the Iceland plume and origin of outwardpropagating V-shaped ridges, J. Geol. Soc. London, 152, 1039-1045.

White, W. M., M. M. Cheatham, and R. A. Duncan (1990), Isotope geochemistry of Lag 115 basalts and inferences on the history of the Réunion mantle plume, Proc. Ocean Drill. Program Initial Rep., 115, 53-61.

Yale, M. M., and J. P. Morgan (1998), Asthenosphere flow model of hotspot-ridge interactions: A comparison of Iceland and Kerguelen, Earth Planet. Sci. Lett., 161, $45-56$. 